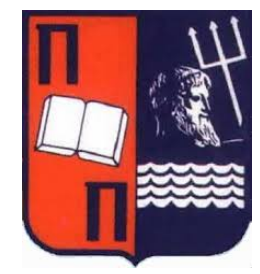

UNIVERSITY OF PIRAEUS

SCHOOL OF ECONOMICS, BUSINESS AND INTERNATIONAL STUDIES

DEPARTMENT OF ECONOMICS

HUMAN CAPITAL, TRADE FLOWS AND TECHNOLOGY BALANCE

Ph.D. Thesis

Georgios Psachoulias

A DISSERTATION SUBMITTED

TO THE DEPARTMENT OF ECONOMICS

OF UNIVERSITY OF PIRAEUS

IN PARTIAL FULLFILLMENT OF THE REQUIREMENTS

FOR THE DEGREE OF DOCTOR OF PHILOSOPHY

Piraeus, 19-05-2021 


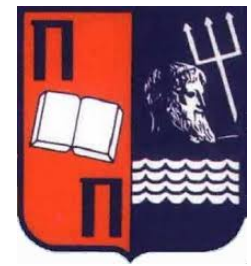

ПАNЕПIГТНМIO ПЕIPAIA

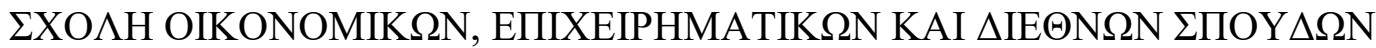

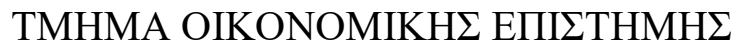

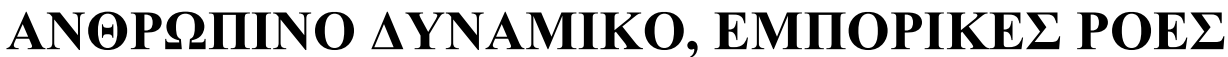

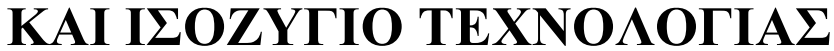

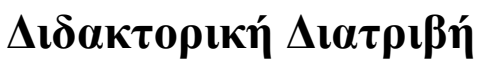

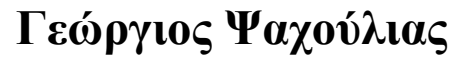

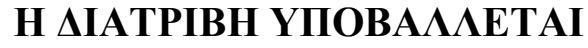

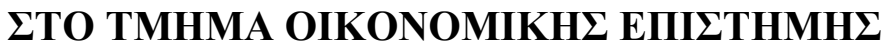

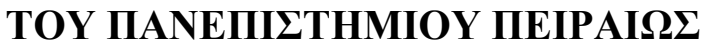

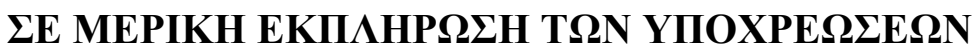

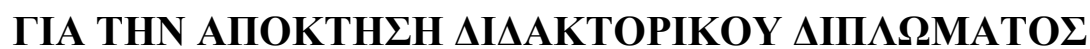

Пєцрนи́์, 19-05-2021 


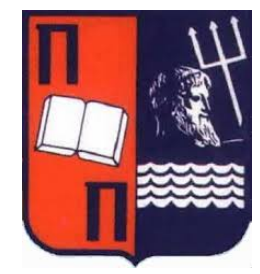

UNIVERSITY OF PIRAEUS

SCHOOL OF ECONOMICS, BUSINESS AND INTERNATIONAL STUDIES

DEPARTMENT OF ECONOMICS

HUMAN CAPITAL, TRADE FLOWS AND TECHNOLOGY BALANCE

Ph.D. Thesis

Georgios Psachoulias

Supervisor: Professor Sotiris Karkalakos

Piraeus, 19-05-2021 


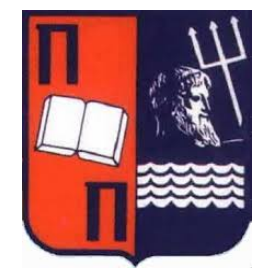

UNIVERSITY OF PIRAEUS

SCHOOL OF ECONOMICS, BUSINESS AND INTERNATIONAL STUDIES

DEPARTMENT OF ECONOMICS

HUMAN CAPITAL, TRADE FLOWS AND TECHNOLOGY BALANCE

Ph.D. Thesis

Georgios Psachoulias

\section{Defense Committee}

Professor Sotiris Karkalakos

Professor Michalis Chletsos

Professor Dimitris Yiannelis

Associate Professor Nikos Benos

Associate Professor Konstantina Kottaridi

Assistant Professor Markos Tselekounis

Assistant Professor Prodromos Vlamis

Piraeus, 19-05-2021 


\section{Acknowledgements}

First and foremost, I want to thank my Supervisor Professor Sotiris Karkalakos whose expertise was invaluable in formulating the research questions and methodology. Your insightful feedback pushed me to sharpen my thinking and brought my work to a higher level. In addition, I would like to thank my parents, Helen and Athanasios, for their wise counsel. You are always there for me. Moreover, I could not have completed this dissertation without the support of my wife Vivi, my daughter Helena and my newborn, who provided continuous support as well as happy distractions to rest my mind outside of my research. Finally, I would like to thank my Uncle Panagiotis and my Aunt Efi for their continuous guidance and so many more things.

Georgios Psachoulias 


\begin{abstract}
This dissertation aims to evaluate the following topics and issues. Chapter 1 introduces the topic of patents and knowledge spillovers. One of the most challenging issues in the recent literature on innovation has been related to the "geography of innovation" or "spatial clustering of innovations". The relationship between technology and geography is a topic of growing interest in both economics and regional science. The main questions are the extent that knowledge spillovers (knowledge externalities) are geographically localized and their impact on the innovative performance of regions. Chapter 2 shows that patents, industrial and university research, and human capital in firms have similar patterns of spatial correlation. Actually, they suggest that research conducted by firms and universities has a strong effect on the count of product patents observed in USA. This finding suggests local knowledge transfers. In addition to searching for evidence of local knowledge effects, the spatial extent of these effects gets particular attention in this chapter. Chapter 3 examines how the spatial concentration of innovation activity shapes the production of innovation in the US states. We augment the standard knowledge production function with a structure that allows for spatial effects, income effects and trade effects. We account not only for bilateral influences, but also for effects from the rest of the states in technology production. In doing so, we avoid overestimating the effect of local and external technological knowledge in producing local technological products. Chapter 4 summarizes the results.
\end{abstract}




\section{Пврі́і $\eta \psi \eta$}

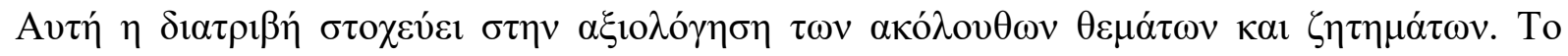

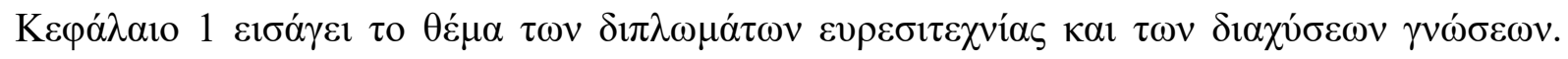

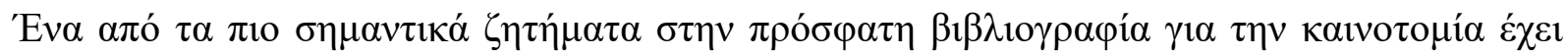

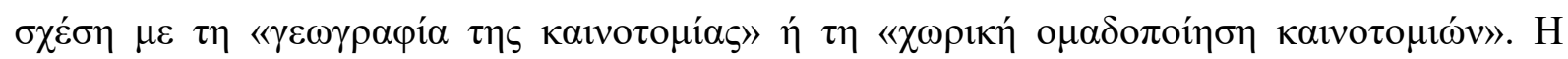

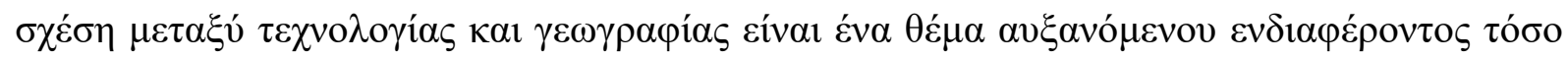

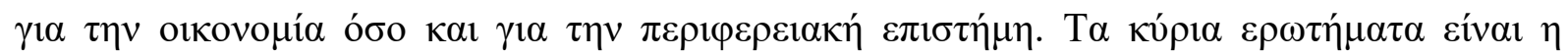

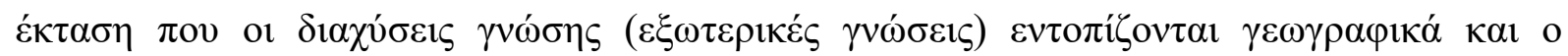

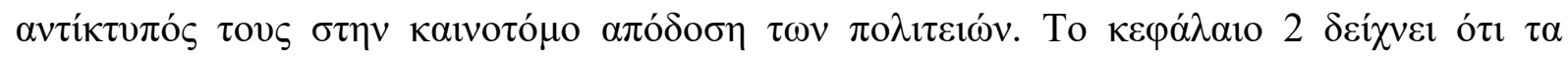

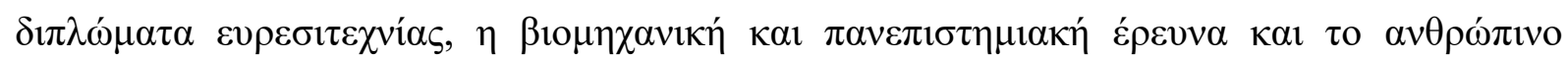

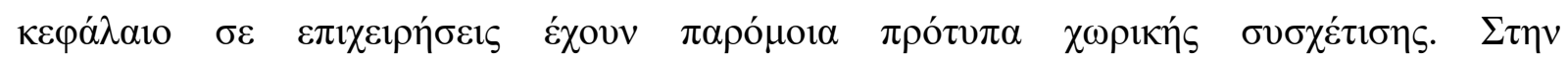

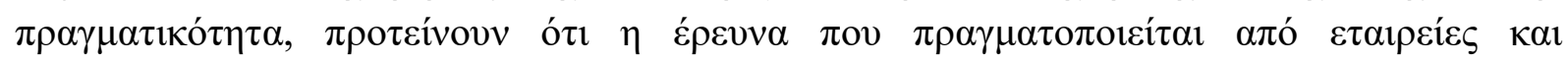

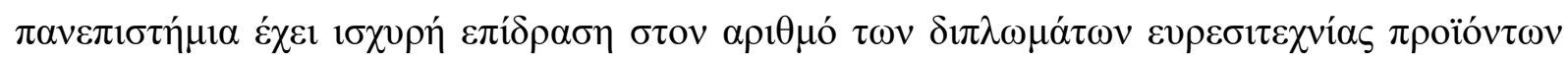

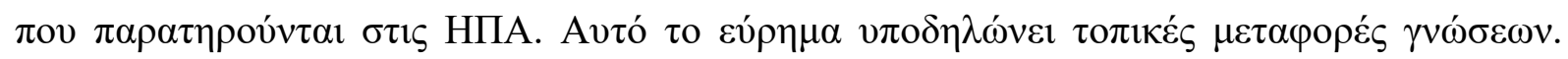

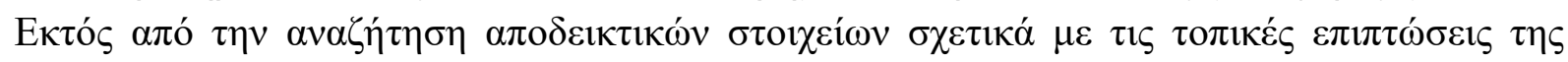

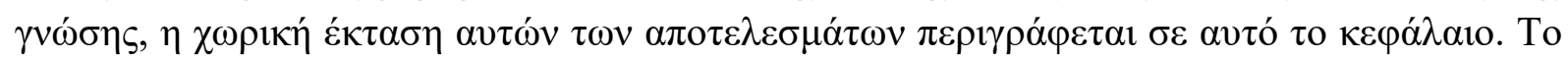

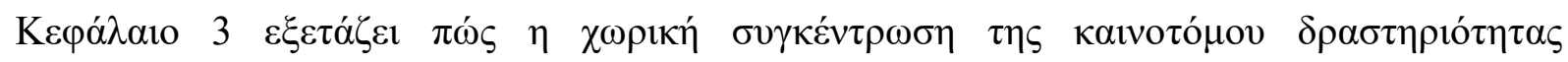

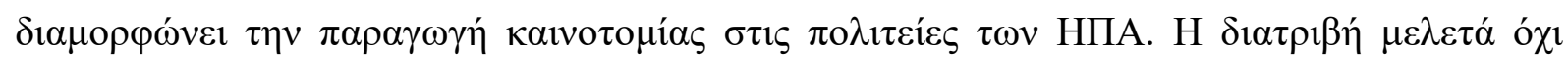

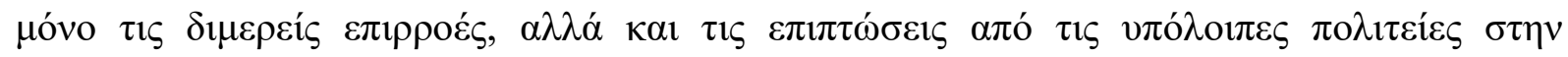

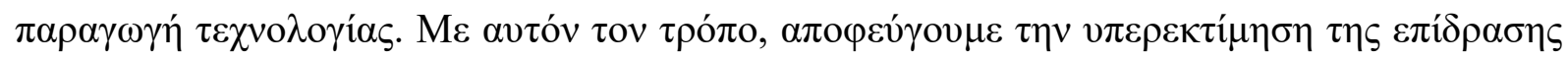

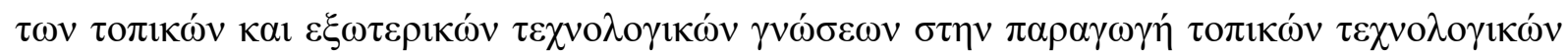

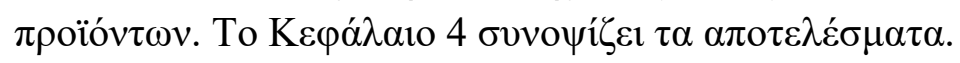


Table of contents

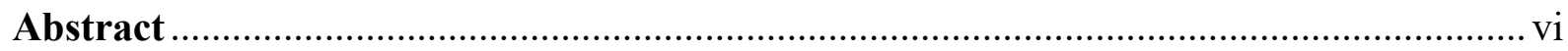

Пврі́

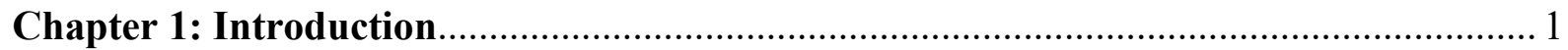

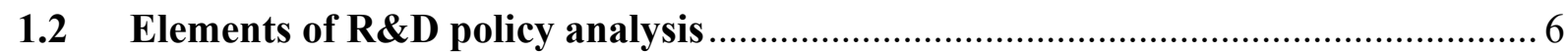

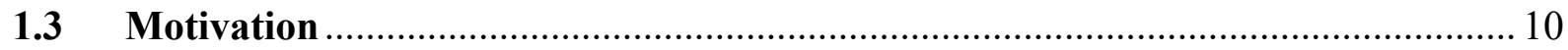

1.4 Research Policy per Region ........................................................................ 14

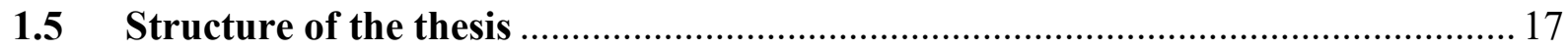

Chapter 2: Human Capital, Trade flows and Technology Production .............................. 18

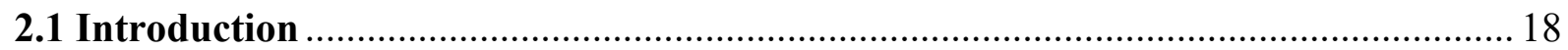

2.2 Spatial Dependence in Regression Models ............................................................. 18

Chapter 3: Growth and Technology Production Conglomerative Effects......................... 30

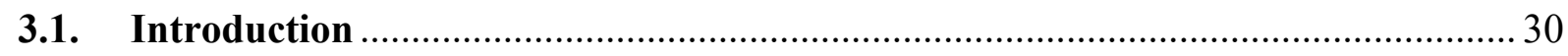

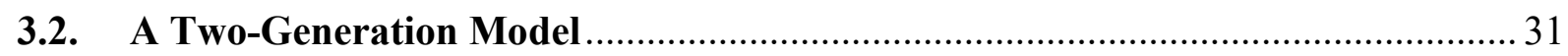

3.3. Empirical Methodology ……………………………………………………… 33

3.3.1 A Spatial Knowledge Production Function …………………………...................... 33

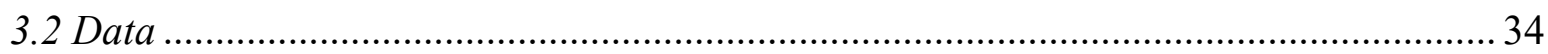

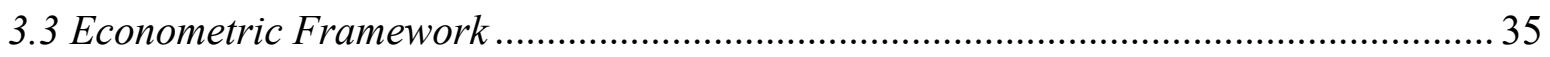

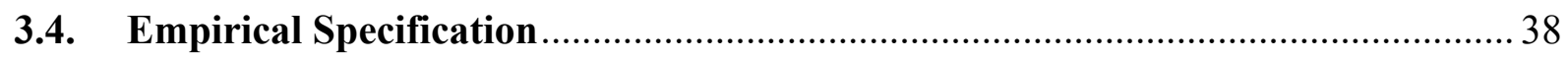

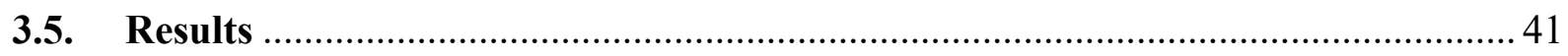

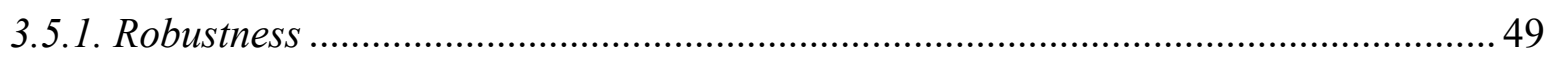

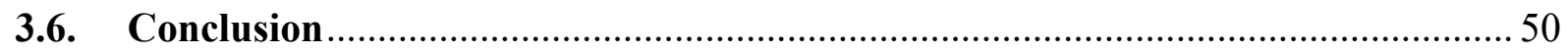

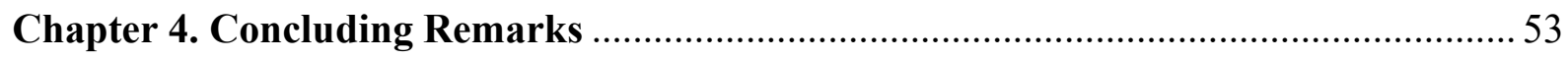

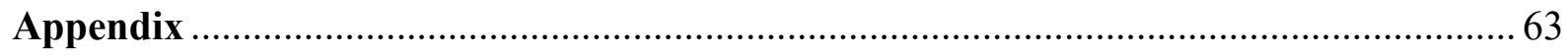




\section{List of Tables}

Table 1.1: Productivity of Patents in EU, USA and Japan for year 2016

Table 2.1: Diagnostics for Spatial Dependence for Variation

$\ln$ Pat $_{i}=\alpha_{0}+\alpha_{1} \ln \left(R D_{f}\right)_{i}+\alpha_{2} \ln \left(R D_{u}\right)_{i}+u_{1}$

Table 2.2: Diagnostics for Spatial Dependence for Variation

$\ln P a t_{i}=\alpha_{0}+\alpha_{1} \ln \left(R D_{f}\right)_{i}+\alpha_{2} \ln \left(R D_{u}\right)_{i}+\alpha_{4} \ln \left(L_{f}\right)_{i}+\alpha_{5} \ln \left(L_{u}\right)_{i}+u_{2}$

Table 2.3: Diagnostics for Spatial Dependence for Variation (3).

Table 2.4: Summary of Research Questions and Variations

Table 2.5: A Comparison of the Literature for Knowledge Spillovers between EU and US .. 27

Table 3.1: Spatial Baseline Model at an Industry Level using Geographic Weights.

Table 3.2: Spatial Baseline Model at an Industry Level using Economic Weights (State Income).

Table 3.3: Negative Binomial Geographic Estimates of Innovation Production (dep. var.: count of patents) .44

Table 3.4: Results with Economic Weights (dep. var.: count of patents) .45

Table A.1: The Distribution of Patents, R\&D of Firms and Universities, and Employment in USA [2000-2017] 63

Table A.2: Descriptive ${ }^{1}$ Statistics of Data. 64 


\section{List of Figures}

Figure 1.1: A schematic presentation of innovative system................................................ 2

Figure 1.2: A schematic presentation of innovative system............................................ 4

Figure 1.3: Three different levels of the environment of innovations ................................. 6

Figure 1.4: Technology commercialization process ….................................................. 7

Figure 1.5: Social benefit from the existence of R\&D policies ....................................... 8

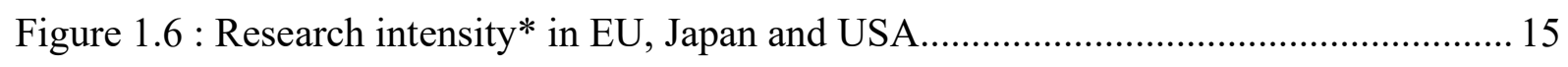

Figure 1.7 : Private and total sector shares of researcher workforce ................................... 16

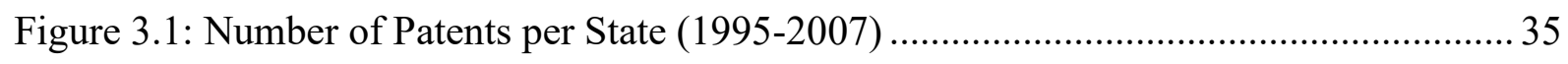




\section{Chapter 1}

\section{Introduction}

While we would expect that cross-border patents are used to protect a technology that is made available in another state in United States, that technology could either be produced locally or imported. International patent filings could therefore be either complements or substitutes to international trade. This thesis combines data on patenting and trade for 50 States between 2000 and 2017 with a panel data model that addresses several biases emphasized in the trade literature in order to provide a systematic analysis of how bilateral trade responds to cross-border patent filings.

\subsection{Patents and Knowledge Spillovers}

One of the most challenging issues in the recent literature on innovation has been related to the "geography of innovation" or "spatial clustering of innovations". The relationship between technology and geography is a topic of growing interest in both economics and regional science. The main questions are the extent that knowledge spillovers (knowledge externalities) are geographically localized and their impact on the innovative performance of regions. The main hypothesis is that knowledge spillovers are space dependent because spatial proximity is important in the transmission of knowledge and ideas.

The starting point of recent studies on knowledge spillovers is the observation that there is a clustering of innovative activities over space, both in the United States and Europe (Breschi and Lissoni, 2001). The clustering of innovative activities over space is based on the observation that firms located in areas with a significant degree of research and development (R\&D) or other innovative inputs, are more likely to exhibit higher levels of innovative performance. There are three main elements that characterize the study of knowledge spillovers - standard methodologies (such as the knowledge production function), data sets (such as innovation and patents), and concepts (such as "tacit knowledge" vs. "freely available information"). The geographical dimension of absorbing knowledge spillovers results from the distinction between tacit and codifiable knowledge (Breschi, 1998). Tacit knowledge is embodied in people and cannot be transferred by other ways than personal contact. In contrast, codifiable knowledge can be put down in written form and can thus be 
studied independently of personal contacts. Geographical distance is important mainly for tacit knowledge. As Audretsch (1998) puts it:

"The theory of knowledge spillovers, derived from the knowledge production function, suggests that the propensity for innovative activity to cluster spatially will be the greatest in industries where tacit knowledge plays an important role. It is tacit knowledge, as opposed to information, which can only be transmitted informally, and typically demands direct and repeated contacts."

It follows that it is up to the researchers to agree about some rules for sharing (and possibly diffusing) the benefits of the discoveries they make. Their publications may convey tacit messages about the authors' knowledge assets in order to arouse the interest of potential research partners, depending on their geographical location (Hicks, 1995 and Feldman 1994, 1999).

According to Acs et al (2012), an innovative system includes not only networks of innovative companies with research organizations, suppliers and customers, but also institutional factors, such as the way publicly financed research is organized in a given country, or the nation's system of schooling, training and financial institutions. Figure 1.1 provides a schematic representation of the key elements of an innovative system.

Figure 1.1: A schematic presentation of innovative system

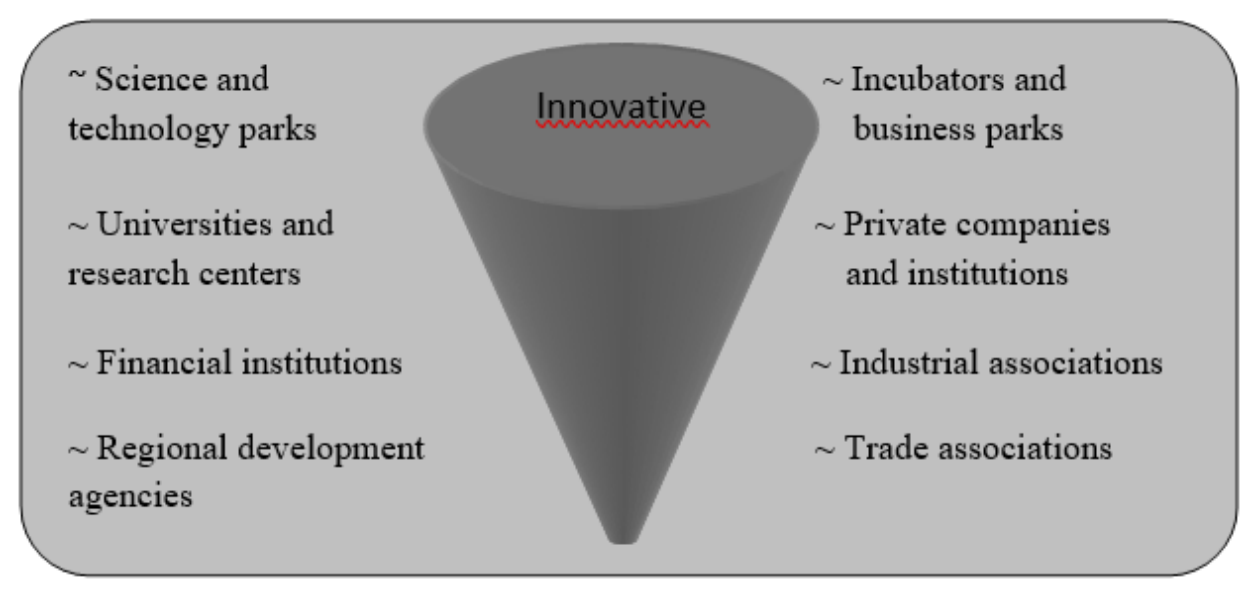

Source: European Commission, 2020

Advances in the state of knowledge have been responsible for much of economic growth. Universities and firms are among the most important factors for technological and economic development. A survey conducted by Mansfield (1995) supports this view. Corporate R\&D managers were asked to mention any academic 
researcher who had played some role in the development of their companies' new products and processes. In the large majority of the cases, academic researchers received research funds from the industry or had entertained continuing consulting relationships within it.

The relationship between investment (public and private) in research and development, innovative products and processes and regional economic growth is well established. The work conducted by Zucker, Darby and Armstrong (1998) supports the above conclusion. It is not an accident that those regions which have high levels of investment in research and development, and innovation are also those with relatively high levels of economic growth. Investment in these fields is a prerequisite for sustained regional development. This includes investment in higher education which plays a pivotal role in the dissemination of new ideas and new technology.

Just as disparities exist in economic growth performance throughout the European Union's region, so disparities exist in regions' research capacity and potential. Studies which the European Union has carried out show that the scale of the disparities in $R \& D$ are far greater than the socio-economic disparities between regions. Reducing the disparities calls for a wider spread of research and development infrastructure, qualified personnel and a technology transfer capacity. In the European Union, $60 \%$ of total (private and public) R\&D expenditure is concentrated in Germany, France and the United Kingdom and is highly unevenly distributed between regions and within member states. In the 1990's productivity grew in Europe, on average, 18 per cent less than in the United States. The European productivity rate of patents varies from country to country, but no one did better than the U.S. By the end of the decade the gap with the U.S. was 7 per cent in Italy, 9 per cent in France and 12 in the Netherlands, three relatively good cases, but a 25 per cent in Denmark.

Companies in the electronics and information technology sectors often cluster in a particular location. This can sometimes be explained by the presence of wellestablished and reputable centers of excellence or university research departments, which provide qualified personnel as well as undertaking innovative projects. Concentration can become a self-reinforcing process as good research results encourage further investment. The latter tendency towards concentration raises important questions for public policy.

Although it is clear that all regions cannot have similar levels of research infrastructure, each should at least have the technology transfer structures which will 
allow it to use to its advantage the fruits of research elsewhere. Therefore, the European Union has a role to play in this regard (European Commission, 2001). Through the research projects under the $R \& D$ framework program, a better regional balance is supported. Private sector has a discrete role but no political power and thus it is not so effective. In addition, education programs assist the rapid dissemination of research findings, while other programs seek to strengthen the infrastructure for innovation through establishing intra-community networks.

Figure 1.2 provides a basic schematic representation of economic activities and the role of innovation in production process (Aghion and Howitt, 1998). This figure illustrates that a firm can possibly split its labor force in a research department and a manufacturing division. In the research department workers are supposed to invent new products or technologies standards, while workers in the manufacturing division produce intermediate goods, that are used to create the final output of the particular firm. On the other hand, public knowledge is enhanced by research performed at universities and research institutions. Their output in the form of knowledge is often published in scientific journals or transmitted by channels such as conferences. This improves the overall knowledge stock in the economy and induces innovative activities. By means of education the labor force becomes more productive because individuals obtain a higher skill level. These skills can be applied in any department of the firm. The latter results in higher levels of innovative activities in the research department on the one hand and higher levels of production in the manufacturing division on the other.

Figure 1.2: A schematic presentation of innovative system

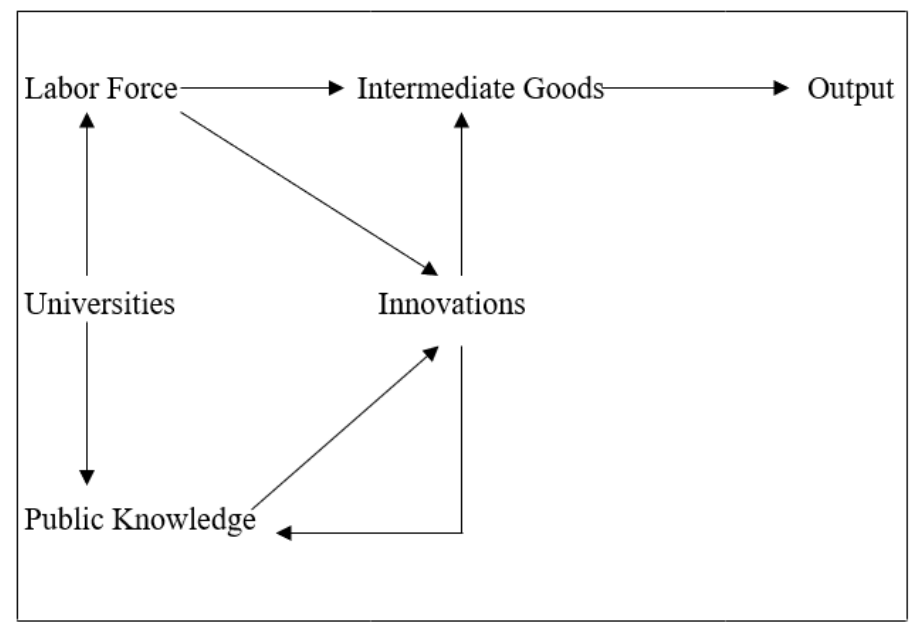

Source: Aghion and Howitt, 1998. 
A peculiar feature of $R \& D$ is that a firm or a university investing in it is often unable to exclude others from freely obtaining some of the benefits. Accounting for these spillovers should contribute to the explanatory power of our model. It has been suggested, however, that these spillovers are merely a specification error (Basu et al, 1995). These interdependencies have important implications for public policies, in addition to the private investment strategies. In other words, public policies and private investment strategies inform each other through a hierarchy of causality, as opposed to being strictly independent of one another.

Organization theorists (i.e., Castrogiovanni, 1991) have studied such interdependencies in the context of organization-environment relationships. They propose a hierarchy of causality among different aggregations of organization's environment. As illustrated in Figure 1.3, the broadest level, defined as the policy environment, (i.e. the rules of patent enforcement) influences task environments (i.e. markets in which patents are enforced) which in turn, influences smaller subenvironments (i.e. resource pools defined by R\&D projects). Higher level forces of the larger environments thus have transitive effects on lower levels of environment. Henceforth, as suggested by the relative size of areas circumscribed by policy, market and policy environments, illustrated in Figure 1.3, influence the supply of new inventions through their effect on the investment strategies (R\&D expenditures) of inventors. 
Figure 1.3: Three different levels of the environment of innovations

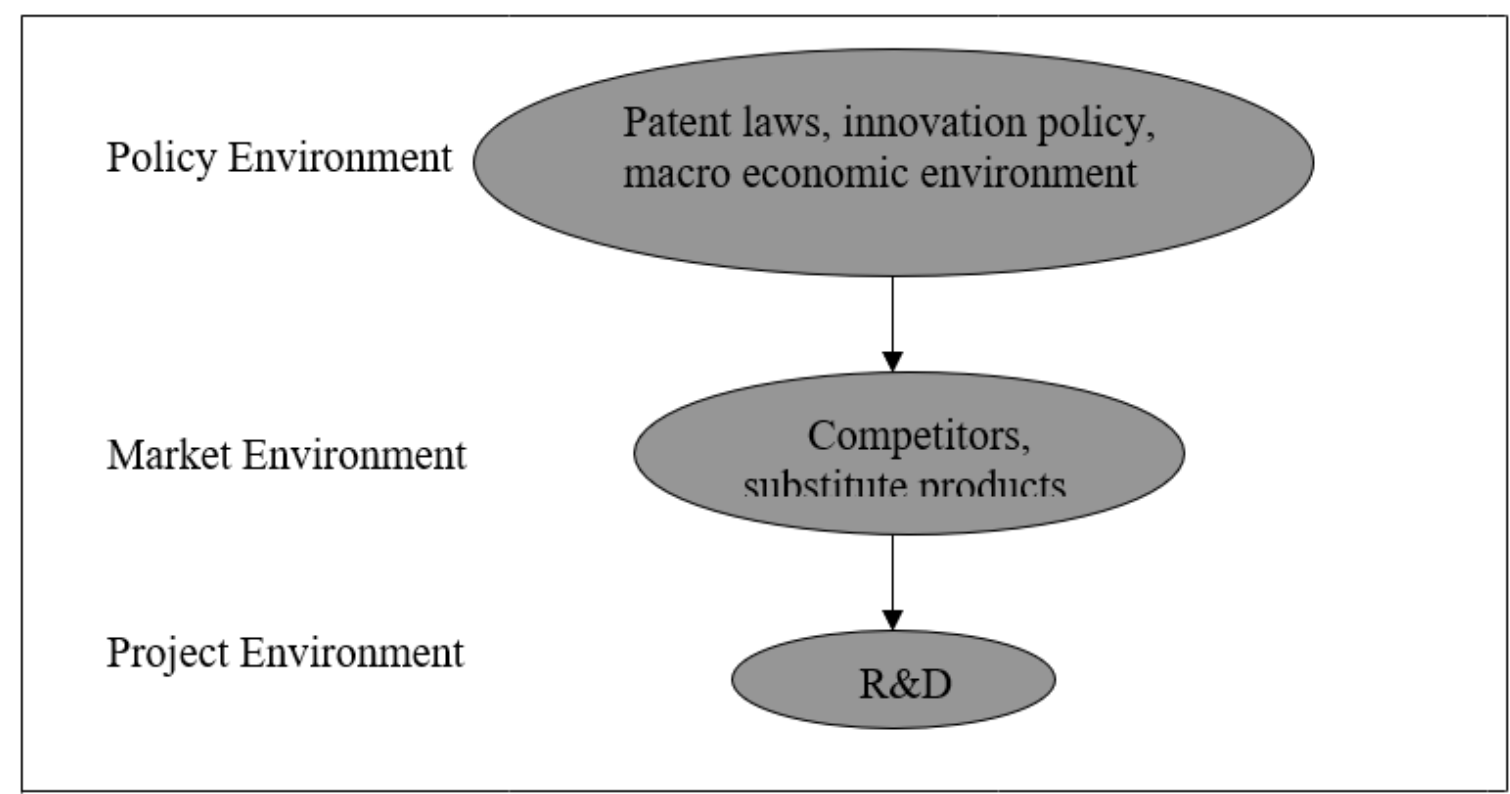

Source: Castrogiovanni, 1991.

\subsection{Elements of $R \& D$ policy analysis}

Effective policy mechanisms and subsequent desirable economic impacts only result from an efficient policy process, and no policy process can be effective without an understanding of how technology-based economic growth really works. However, most industrialized nations implement R\&D policies based on minimal analytical input. As a result, the appropriate mechanisms are frequently not selected, or are poorly integrated into an overall economic growth policy. Therefore, it is essential to describe the mechanism of a technology-based economic process.

A new invention begins as an investment project, the expected value of which depends on the outcome of initial R\&D policies and efforts, the probability of obtaining valuable property rights protecting the invention (i.e., a patent), and the probability of successfully exploiting that property right. This sequence is described in Figure 1.4. At time 0, the inventor (i.e., a firm) evaluates the alternatives for investment in R\&D projects, based on their expected net profits, given the public's specification of the terms of the patent regime, $\alpha 2$, (i.e., duration, eligible subject matter for patent protection) and makes an $R \& D$ investment, $\alpha 1$. If the results of R\&D are successful (probability S1), the inventor applies for a patent and obtains one with probability S2 at time period 2. Once a patent is obtained, the invention creates 
an expected revenue stream of monopoly rents or licensing fees for the duration of the patent. However, the validity, enforceability and scope of protection of a patent may be challenged in a court [with probability (1-S3) after it has been issued on a variety of grounds (i.e., inability to meet the requirements for patentability), if such evidence is presented to the court in post-issuance litigation. Two factors that affect the validity of a patent, or its ability to generate benefit streams, are disclosed prior art. Each of these may be considered decision variables in the technology commercialization process illustrated on figure 1.4.

\section{Figure 1.4: Technology commercialization process}

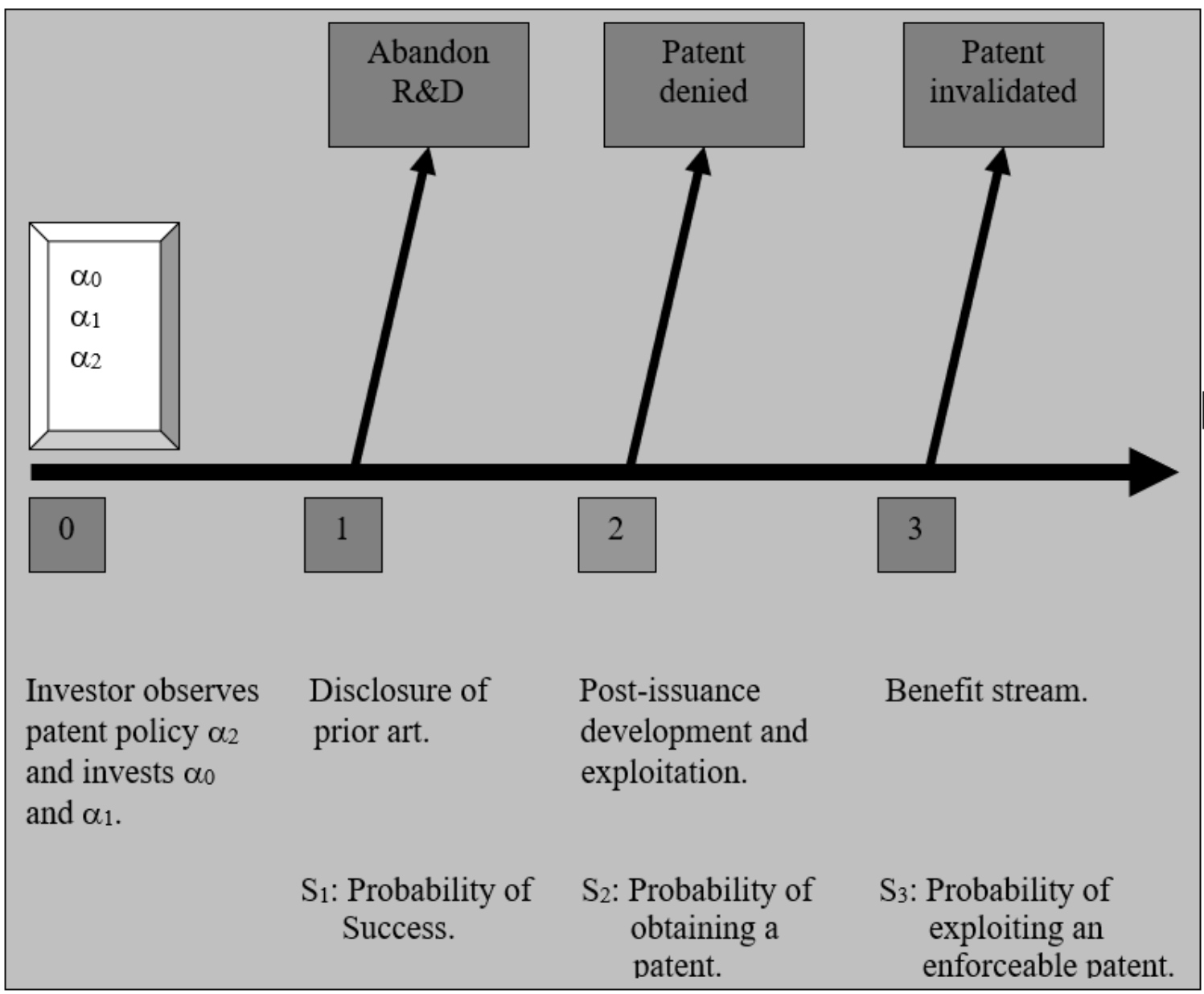

The social benefits from the R\&D policies can be measured by the sum of the two shaded areas in Figure 1.5. The upper shaded area is the consumer surplus resulting from the lower price (P2 instead of $\mathrm{P} 1$ ) arising from using the output (innovation) of R\&D policies. Also, a resource saving (s) is registered, and a corresponding gain in input elsewhere in the economy, because of the resource cost of 
producing the good using the innovation $[\mathrm{P} 3(=\mathrm{P} 2-\mathrm{s})$ instead of $\mathrm{P} 2]$. Thus, in addition to consumer surplus arising from the price cut, a resource saving is present amounting to the innovator's profits. Finally, triangle D represents the deadweight loss for the society because of patent-derived monopoly.

\section{Figure 1.5: Social benefit from the existence of $R \& D$ policies}

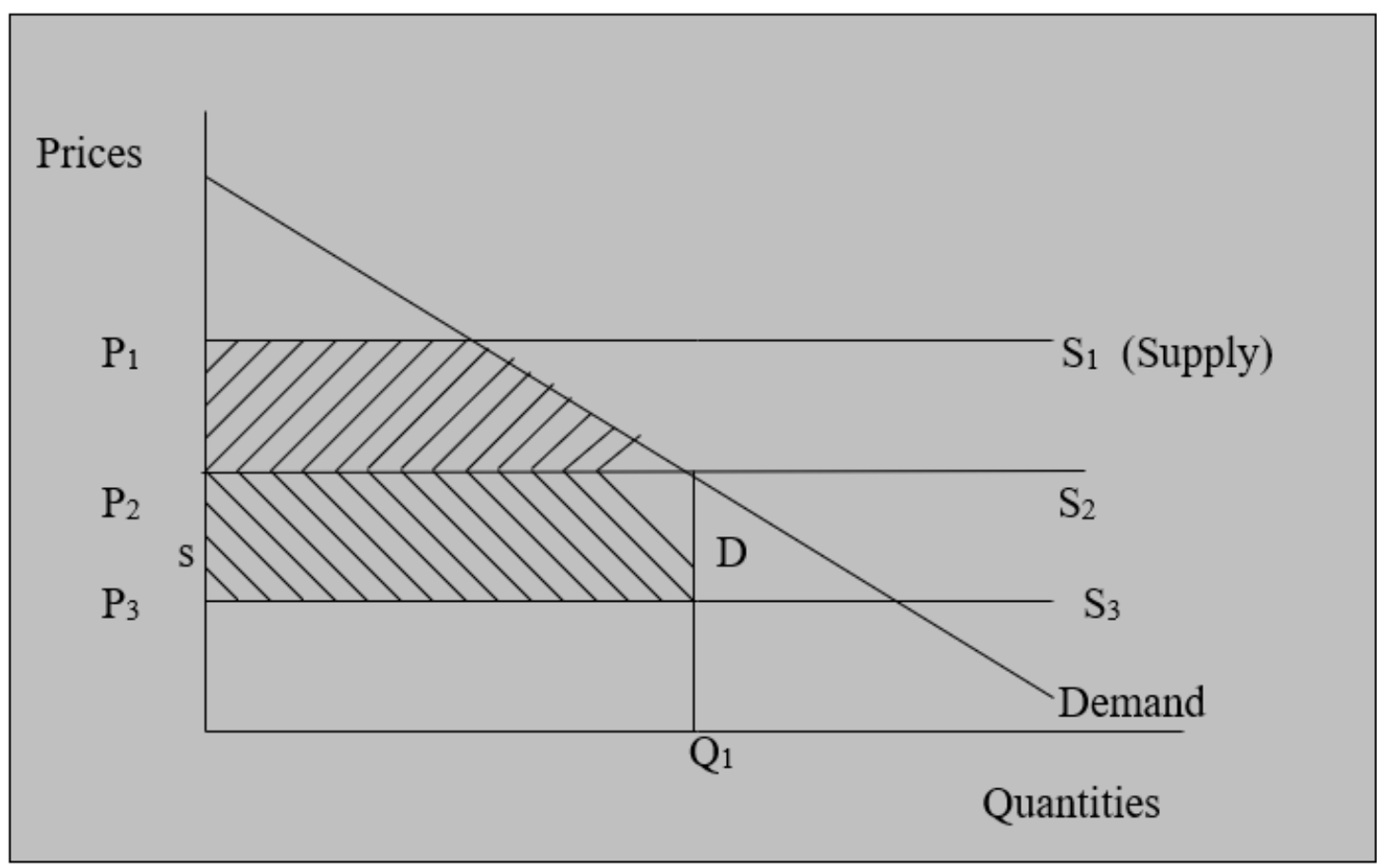

The R\&D policy process in European Union (or US) is largely disconnected organizationally and functionally from traditional economic policy mechanisms. Because technology is the single most important asset for long - term economic growth, it therefore must be treated as an economic variable in a larger economic growth framework. Moreover, because research and development is the process by which most technology is created, policies that affect it must be carefully analyzed.

As discussed in the previous section numerous factors combine to determine technological and economic outcomes, and an equal number of problems can arise with the processes by which these outcomes are realized. Thus, R\&D policies (from both firms and universities) first must be capable of understanding and analyzing the appropriate technological and economic trends, as well as how the major elements of technology-based economic activity interact. From these understandings, the policy 
process must then develop analytically based policy options and convey the derived options in forms that facilitate effective decision making.

Effective R\&D policies are important towards the productivity of new technology. It is essential to understand the assumptions for effective $\mathrm{R} \& \mathrm{D}$ policies so we may explain in a better way the results of our models. According to Breschi (1998) and Breschi and Lissoni (2001), firms and universities have effective R\&D policies when the following principles hold:

- $\quad$ R\&D must be viewed by economic growth policy as an integral investment, along with plant and equipment, education, and conventional infrastructure.

- The R\&D process has a dynamic and iterative character, including numerous feedback loops within longer generation technology life cycle.

- The R\&D process also progresses from pure science and experimental generic technology to market applications, which eventually attain commodity status through sustaining R\&D and evolution of demand.

- The R\&D process requires both public and private investments over the course of the typical technology life cycle.

- Government investment at any phase should be determined by joint industrygovernment identification of various market failures constraining private investment.

- Diversification of R\&D across technologies and geographic regions should be supported, as long as threshold levels of public and private investment in individual technologies can be attained.

- The early phases of $\mathrm{R} \& \mathrm{D}$, particularly the development of generic technologies, must be as truly experimental and unfettered as possible, undertaken in a cooperative mode by industry and universities, and with a constant reappraisal of research progress.

- R\&D policy must embody a "portfolio" perspective, so that proposed national competences in various technologies can be compared and strategies formulated through joint industry-government planning.

- $\quad \mathrm{R} \& \mathrm{D}$ for any one industry or university must be designed and managed in the context of potential opportunities of market failures.

A proactive policy approach based on accurate and convincing microeconomic analysis, can help any industry, or university, extend its planning horizons, pool risks 
associated with investment in emerging technologies with significant economic growth potential, and access cheap capital in time frames required by foreign competition and domestic economic growth objectives.

\subsection{Motivation}

There is a sizeable literature that has documented the important role of universities and firms in the study and the development of innovations (European Commission; 1991, 2000). In recent years, researchers have considered a variety of regional models relating to the latter issue. The issue of allocation of resources in Research and Development $1(\mathrm{R} \& \mathrm{D})$ and the process of diffusion of new ideas are among the most interesting topics of study in modern economies. The basic research question behind this dissertation is to identify and evaluate the effects of research externalities and elasticity of labor with respect to productivity of patents in generating innovation across space. Furthermore, we analyze the importance of research and development and of knowledge diffusion, via spatial spillovers, in shaping the distribution of innovative activity among European regions. Two questions arise: Why is innovation so highly localized among European regions (as in the world)? Does the pattern of innovation follow the pattern of production?

Our approach examines the issue of knowledge spillovers from an explicit spatial econometric perspective (Anselin, 2002), yielding more precise insights into the range of spatial correlation between patents, $R \& D$ expenditure and employment, across different geographical areas. The research is motivated by a critical assessment (Breschi and Lissoni, 2001) on the spatial boundaries of the spillovers from both private and public or academic R\&D institutions. Their survey set a tight research agenda for those who want to understand the role of geography in firms' innovative activity. According to them, it remains to be seen to what extent labor mobility across different sectors of production, such as government or firms, contributes to the creation of a common pool of knowledge. A parallel line of research should deal with assessing more carefully the impact of local academic or public research in innovative activity.

1 Results provide evidence about the view, expressed most thoughtfully in Griliches' American Economic Association's presidential address, that R\&D is an important source of economic growth, but that the size of its effect econometrically is modest. 
This research represents the first attempt in the literature to provide a systematic analysis of the relationship between knowledge spillovers and elasticity of labor, in USA (50 states), at the lowest possible level of spatial aggregation. We do so by analyzing $R \& D$ expenditures (firms and universities), number of patents and employment, using a Cobb-Douglas knowledge production function.

State level analysis is interesting in spatial analysis because it provides more information in the increasingly integrated state markets. Such spatial units achieve a higher degree of homogeneity than country level data, and therefore, they are important components of the formulation of any research and innovation policy (OECD, 2011). This is explained by the fact that smaller spatial units of study allow for better exploration of the routes of transmission of tacit or codifiable knowledge. On the other hand, European regions are rather different in their economic development (GDP per capita, educational level and industrial specialization) ranging from low income and low potential regions in the southern area of European Union to high tech and service-intensive regions in the Franco-German-Benelux core. Our analysis aims to explore and identify those patterns of economic activity using a spatial econometric perspective. The results of our modeling may be compared with the corresponding ones from similar studies for the U.S (Varga, 1998). Bottazzi and Peri (2002) conducted an analysis which estimates the effect of research externalities in generating innovation across the European Union. Our approach may be viewed not as an alternative, but as a natural extension of their approximation.

Two things are worth mentioning up front. First, the decision to invest in R\&D and therefore to innovate, is endogenous to the economic process, and actually driven by the size of the market for an innovation, we do not impose any strong assumption on returns to accumulation of knowledge. Second, the rate of endogenous growth will depend on an average of the $R \& D$ investment across regions, or just convergence to an exogenous growth rate, determined by the growth rate of human capital. What certainly happens is that the relative rate of innovation across regions and the relative rate of growth of human capital depends on the intensity of $R \& D$ in those regions (i.e., the higher the employment rate of researchers the higher the probability to innovate). This very general result about the relative rate of innovation and growth of human capital allows us to estimate, using relative patenting rates, the productivity of $\mathrm{R} \& \mathrm{D}$ in generating innovation and the intensity of spillovers. 
By a number of measures the recent economic performance of USA and European Union has been dynamic. Average GDP per capita in Europe is only about two-thirds that in the United States, and is below that in Japan (Table 1.1). The generally lower level of per capita employment in European Union explains some of the problem, but output per active worker in Europe is still only $83 \%$ of the United States and just higher than Japan's. Associated with the sense of relatively poor aggregate performance is Europe's failure to be a player in 'high-tech' industries as electronics, computer software and biotechnology 2 .

Table 1.1: Productivity of Patents in EU, USA and Japan for year 2016

\begin{tabular}{|c|c|c|c|c|c|c|}
\hline Country & $\begin{array}{l}\text { GDP } \\
\text { per } \\
\text { capita }\end{array}$ & $\begin{array}{l}\text { Employment } \\
\text { per capita }\end{array}$ & $\begin{array}{l}\text { Researchers } \\
\text { in Firms } \\
\text { (Head } \\
\text { Count) }\end{array}$ & $\begin{array}{l}\text { Research } \\
\text { Intensity } \\
(\%)\end{array}$ & $\begin{array}{l}\text { Patenting } \\
\text { Intensity } \\
\text { in } \\
\text { Germany } \\
(1 / 1000)\end{array}$ & $\begin{array}{l}\text { Patenting } \\
\text { Intensity } \\
\text { in the } \\
\text { USA } \\
(1 / 1000)\end{array}$ \\
\hline EU & 19,318 & 48,958 & 375,775 & 0.25 & 0.17 & 0.25 \\
\hline USA & 27,821 & 58,329 & 764,500 & 0.63 & 0.19 & - \\
\hline Japan & 23,235 & 45,049 & 257,074 & 0.39 & 0.21 & 0.56 \\
\hline Belgium & 21,856 & 60,031 & 8,750 & 0.23 & 0.19 & 0.22 \\
\hline Denmark & 22,418 & 46,303 & 5,883 & 0.24 & 0.25 & 0.32 \\
\hline Finland & 18,871 & 46,102 & 5,453 & 0.26 & 0.41 & 0.53 \\
\hline France & 20,533 & 53.508 & 66,455 & 0.29 & 0.24 & 0.25 \\
\hline Germany & 21,200 & 50,376 & 128,956 & 0.36 & - & 0.38 \\
\hline Greece & 12,743 & 34,462 & 1,319 & 0.03 & 0.01 & 0.01 \\
\hline Ireland & 18,988 & 51,799 & 2,576 & 0.21 & 0.11 & 0.14 \\
\hline Italy & 19,974 & 51,173 & 27,932 & 0.14 & 0.38 & 0.11 \\
\hline Luxemburg & 19,678 & 57,201 & 6,902 & 0.19 & 0.16 & 0.14 \\
\hline Netherlands & 20,905 & 52,479 & 11,370 & 0.19 & 0.38 & 0.31 \\
\hline
\end{tabular}

2 See, e.g., European Commission (2020), 'The European Business and Innovation Centres (BICs)'. 


\begin{tabular}{l|llllll} 
Portugal & 13,100 & 30,868 & 481 & 0.01 & 0.01 & 0.01 \\
Spain & 14,954 & 47,302 & 11,256 & 0.09 & 0.03 & 0.03 \\
\hline Sweden & 19,258 & 43,327 & 15,334 & 0.38 & 0.36 & 0.52 \\
UK & 18,636 & 41,416 & 86,100 & 0.33 & 0.17 & 0.27
\end{tabular}

Notes: Source of data is OECD (2017). GDP is translated to current dollars by the OECD using their PPPs. The number of workers is OECD employment. Researchers are R\&D research scientists and engineers employed in firms and universities. Research intensity is the researchers expressed as a percentage of total employment. Patenting intensity is the number of patent applications in either Germany or the USA per thousand workers in the inventor's country. A possible reason is Europe's research performance ${ }_{3}$. European firms and universities, on average, employ a substantially smaller fraction of their workers as researchers, as Table 1.1 reports. Measures of research output are also not flattering to Europe. In 2003, the average worker in Japan applied for over twice as many US patents as the average in the EU.

Table 1.1 shows the figures for the EU overall mask considerable variability within its membership. Some European countries, such as Germany, France and Sweden, appear to be leading innovators as measured by either research intensity or patenting intensity, but some other countries, such as Greece and Portugal, present very low indexes. On average, Europe's low research output is likely explained by the existence of barriers to disperse the amount of productive knowledge.

If a stagnant research sector is the problem, why has EU been less innovative than the USA and Japan? There are two possible answers. One is that research is not rewarded in Europe to the extent that it is elsewhere. Low rewards could be the consequence of fragmented markets, weak patent protection or the absence of subsidies. Another answer is that EU is just not very good at doing research, either because it has fallen too far behind the technological frontier, or because it lacks the necessary research infrastructure 4. 3 Research performance is measured in terms of number of patents per region, for the purposes of our
study.

4 Schookler (1966) emphasizes the importance of market size, in contrast to research productivity, as a determinant of innovative activity. 
The two explanations suggest different policy responses. Market integration, more effective and cheaper patent protection, and government subsidies increase the rewards to innovative activity. Different approaches to promoting innovation have very different impacts, especially in an international context. Government subsidies typically support activities carried out domestically, regardless of where the results get used, while patents reward research that ends up being used domestically, regardless of where it took place. A government or a university research lab may promote innovation locally, or may spur inventive activity worldwide. On the cost side, government subsidies and spending on infrastructure use up tax revenue, while tougher patent protection and regulation inhibit competition.

The basic picture that emerges is that research in European Union is very responsive to various types of research policy. Direct research subsidies have a substantial effect on research inputs (Bottazi and Peri, 2003). It is true that European Union suffers relative to the United States from having smaller and more fragmented markets for its innovations. Several European countries lack in intrinsic capacity to do research or in research infrastructure. Among the countries where research effort would have the most significant result (in terms of raising average income) are Germany, France and Netherlands (European Commission, 2000).

A crucial factor seems to be the lower appropriability of the benefits of innovation that European firms face in other European countries. According to Breschi (1998), the rate of imitation (violating patent copy rights) for innovations patented outside the innovator's home country is five times higher than the rate for innovations patented inside the innovator's home country. If the difficulty is the cost of defending the patents in different local legal systems, a unified European patent with a single court of appeal might solve the problem. If the problem is narrow patent breadth, strengthening patent rights, either locally or within a unified European patent system, would be a more appropriate response. The latter will create a better environment for innovations.

\subsection{Research Policy per Region}

Eurostat data reports expenditure on $R \& D$ by region broken down by sector of performance. Of particular interest are: (1) R\&D performed by firms, and (2) Aggregate (Total) R\&D. The first measure might be called private sector research while the latter includes a narrow and broad measure, respectively, of government 
research support (in both firms and universities). Eurostat reports the employment of R\&D scientists and engineers by sector of employment.

Europe's third place ranking is presented in Figure 1.6, where two measures of research intensity are described for European Union, Japan and the United States during 1990-1996. For both the expenditure-based measures, one version incorporates research in all sectors and one includes only private sector research. According to that measure Japan and USA are consistently ahead of European Union.

An increasingly debated issue is the nature of participation by universities in collaborative research. One may argue that industry can fund enough generic technology research and that, if adequate labor force and facilities are not available, firms can turn to universities to fill the gaps. Moreover, proponents of university research point to shifts by many academic institutions toward doing research with market objectives, patenting the resulting intellectual property, and even spinning off new companies to further develop and commercialize the new technology.

Figure 1.6 : Research intensity* in EU, Japan and USA

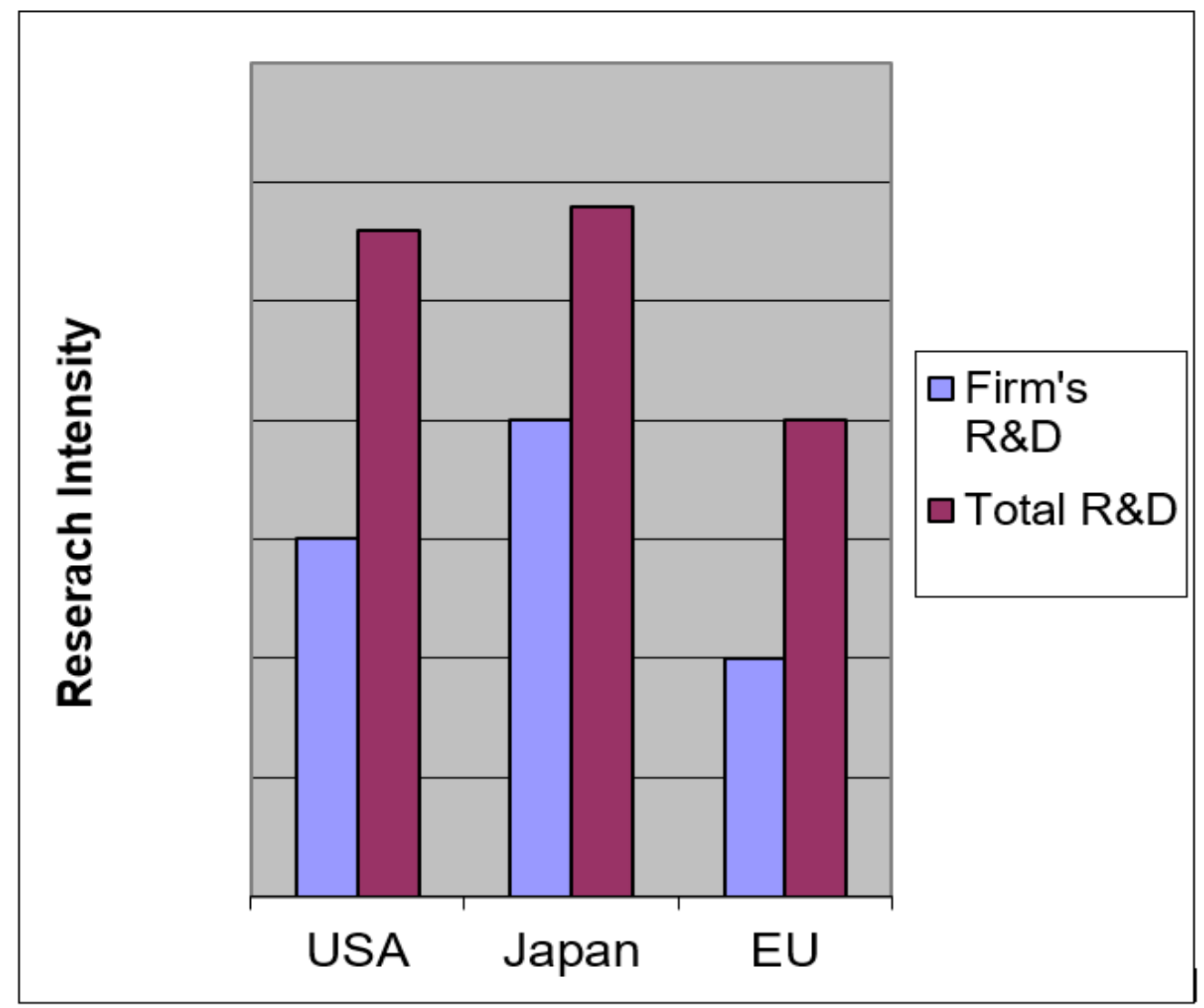

Source: Eurostat, 2017.

* Number of researchers per million of euros of R\&D expenditures. 
However, when time and market factors are less of a concern, a firm may participate in a university-industry collaborative project. University research may play a larger role here as participating firms' objective are focused on determining if a new technology should be adopted for their R\&D portfolio and assessing the set of research skills that would be needed if an internal $R \& D$ project in this area were to be initiated.

Figure 1.7 : Private and total sector shares of researcher workforce

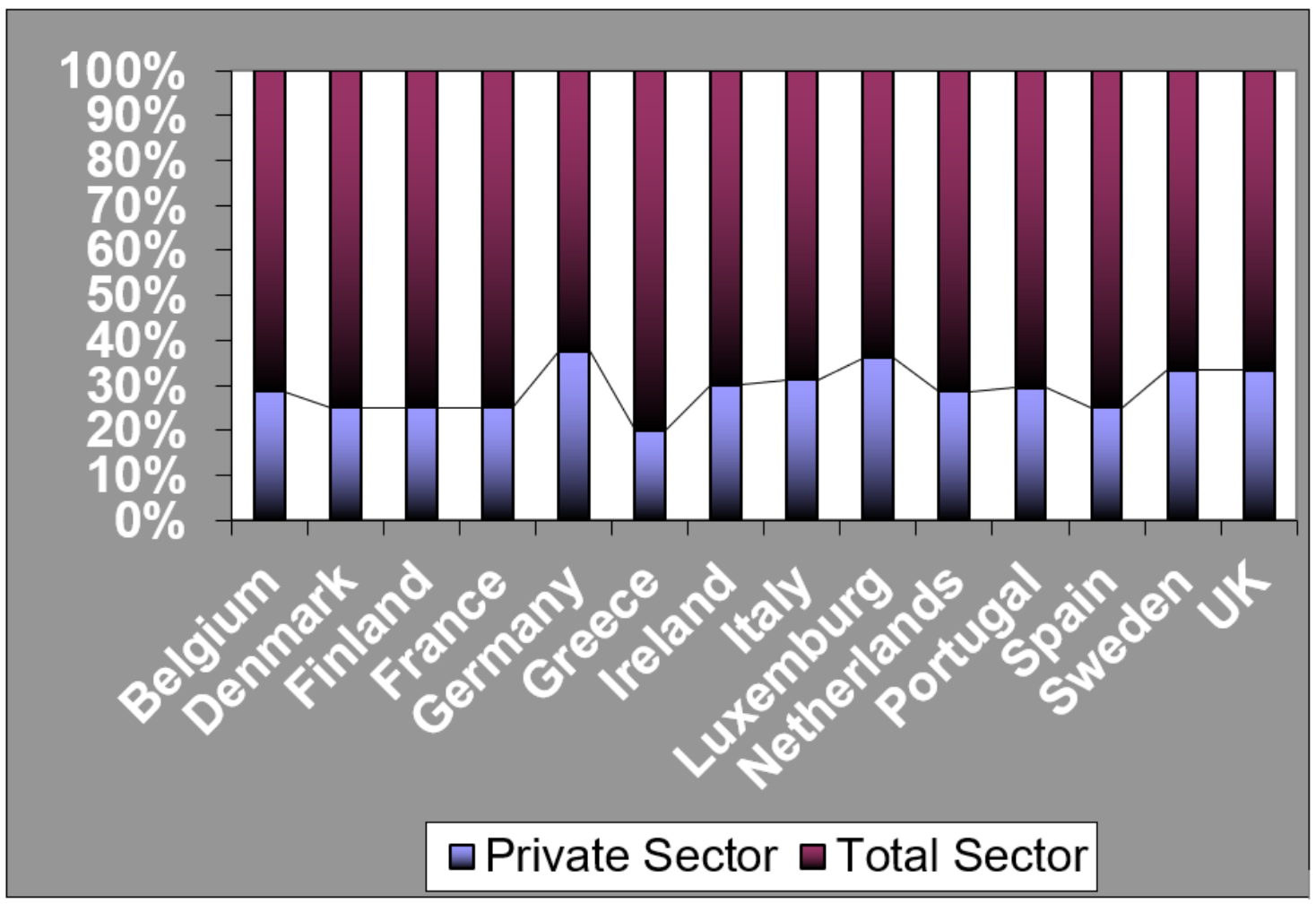

Source: Eurostat, 2017.

Notes: Private sector=Percentage of researchers who work in private companies, Total sector $=$ Percentage of researchers who work in universities and government

Such research is appropriately open ended in that it has not become an explicit objective of the firm's R\&D strategy.

Figure 1.7 focuses on the employment-based measures of research intensity, across all of the 14 European Countries. The shaded bars portray total and private research scientists and engineers 5 . It is important to note the tremendous variation in

5 It refers only to European citizens. 
research effort within Europe, especially in the private sector. Some individual European Countries, such as Germany, Sweden, and United Kingdom, are highly research intensive. On the other hand, Greece and Portugal devote only a tiny fraction of their resources to research. The disparity in the absolute scale of research between the large and the small countries of Europe is even greater.

\subsection{Structure of the thesis}

The remainder of the dissertation is organized as follows. Chapter 2 shows that patents, industrial and university research, and human capital in firms have similar patterns of spatial correlation. Actually, they suggest that research conducted by firms and universities has a strong effect on the count of product patents observed in USA. This finding suggests local knowledge transfers. In addition to searching for evidence of local knowledge effects, the spatial extent of these effects gets particular attention in this chapter. Chapter 3 examines how the spatial concentration of innovation activity shapes the production of innovation in the US states. We augment the standard knowledge production function with a structure that allows for spatial effects, income effects and trade effects. We account not only for bilateral influences, but also for effects from the rest of the states in technology production. In doing so, we avoid overestimating the effect of local and external technological knowledge in producing local technological products. Chapter 4 summarizes the results. 


\section{Chapter 2}

\section{Human Capital, Trade flows and Technology Production}

\subsection{Introduction}

It was emphasized in the literature review that the Griliches-Jaffe knowledge production function model provides a useful empirical framework to study the direct and indirect effects of knowledge spillovers (i.e., the impact on innovations and the spatial distribution of $R \& D$ activities). The results of the exploratory data analysis in Chapter 2 show that patents, industrial and university research, and human capital in firms have similar patterns of spatial correlation. Actually, they suggest that research conducted by firms and universities has a strong effect on the count of product patents observed in USA. This finding suggests local knowledge transfers. In addition to searching for evidence of local knowledge effects, the spatial extent of these effects gets particular attention in this chapter.

\subsection{Spatial Dependence in Regression Models}

The presence of spatial effects can invalidate OLS estimation. Several diagnostic tests have been developed in the literature to find the appropriate model specification. The Lagrange Multiplier (LM) test, the Lagrange Ratio (LR) test, and the Wald (W) test are all measures of the distance between restricted and unrestricted estimates. Acceptance of the null hypothesis is based on the extent of the distance. A widely used diagnostic test for spatial error dependence is an extension of Moran's I to the regression context ${ }^{6}$.

An important decision in model specification is the choice of spatial weights matrix. Explanatory data analysis provides a possible way to get information about the structure of spatial dependence in the data. The other method used in practice is applying several differently created weights matrices in regression analysis and testing for the presence of spatial dependence with each of the matrices. Tables 2.1, 2.2 and 2.3, present the diagnostic tests for different weight matrices. For the purposes of our study, PAT45 is chosen as the weight matrix for any lag model specification.

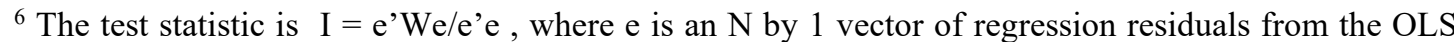
estimation on a sample with $\mathrm{N}$ observations, and $\mathrm{W}$ is a (typically row-standardized) $\mathrm{N}$ by $\mathrm{N}$ weights matrix. Inference is based on the normal distribution.
} 
PAT45 is distance-based contiguity of 450 miles, the average distance among any two neighboring states. It is chosen as the weight matrix which describes the neighboring relationships among the observations of our data since it presents the highest values (lowest p-value) among different weights no matter the choice of model specification. Therefore, the distance matrix (PAT45) is robust no matter the choice of the econometric model.

Table 2.1: Diagnostics for Spatial Dependence for Variation (1)

$\ln P a t_{i}=\alpha_{0}+\alpha_{1} \ln \left(R D_{f}\right)_{i}+\alpha_{2} \ln \left(R D_{u}\right)_{i}+u_{1}$

\begin{tabular}{|c|c|c|c|c|}
\hline Test & Weight & MI/DF & Value & P-value \\
\hline Moran's I & PAT45 & 0.010711 & 0.642862 & 0.052033 \\
\hline $\begin{array}{l}\text { Lagrange } \\
\text { Multiplier } \\
\text { (error) }\end{array}$ & PAT45 & 1 & 0.543016 & 0.461185 \\
\hline $\begin{array}{ll}\text { Robust } & \text { LM } \\
\text { (error) } & \end{array}$ & PAT45 & 1 & 0.238007 & 0.625649 \\
\hline $\begin{array}{l}\text { Lagrange } \\
\text { Multiplier (lag) }\end{array}$ & PAT45 & 1 & 6.651016 & 0.009910 \\
\hline $\begin{array}{l}\text { Robust LM } \\
\text { (lag) }\end{array}$ & PAT45 & 1 & 6.346007 & 0.011765 \\
\hline Moran's I & PAT16 & 0.106567 & 0.776895 & 0.000159 \\
\hline $\begin{array}{l}\text { Lagrange } \\
\text { Multiplier } \\
\text { (error) }\end{array}$ & PAT16 & 1 & 9.782058 & 0.001762 \\
\hline
\end{tabular}




\begin{tabular}{|c|c|c|c|c|}
\hline $\begin{array}{l}\text { Robust } \quad \text { LM } \\
\text { (error) }\end{array}$ & PAT16 & 1 & 0.659560 & 0.416715 \\
\hline $\begin{array}{l}\text { Lagrange } \\
\text { Multiplier (lag) }\end{array}$ & PAT16 & 1 & 21.623269 & 0.000003 \\
\hline $\begin{array}{l}\text { Robust } \quad \text { LM } \\
\text { (lag) }\end{array}$ & PAT16 & 1 & 12.500771 & 0.000407 \\
\hline Moran's I & NEIG4 & 0.113021 & 0.451817 & 0.014214 \\
\hline $\begin{array}{l}\text { Lagrange } \\
\text { Multiplier } \\
\text { (error) }\end{array}$ & NEIG4 & 1 & 4.538537 & 0.033140 \\
\hline $\begin{array}{l}\text { Robust } \quad \text { LM } \\
\text { (error) }\end{array}$ & NEIG4 & 1 & 2.638994 & 0.104270 \\
\hline $\begin{array}{l}\text { Lagrange } \\
\text { Multiplier (lag) }\end{array}$ & NEIG4 & 1 & 20.884991 & 0.000005 \\
\hline $\begin{array}{l}\text { Robust } \quad \text { LM } \\
\text { (lag) }\end{array}$ & NEIG4 & 1 & 18.985448 & 0.000013 \\
\hline
\end{tabular}

Note: PAT16 is distance-based contiguity for 160 miles; PAT45 is distance-based contiguity for 450 miles; and NEIG4 is a contiguity matrix based on the 4 nearest neighbors. Critical value for LM-Error and LM-Lag is $3.84(\mathrm{P}=0.05)$. LM Error test robust to Lag and LM Lag test robust to error adjust LM $\square$ test statistic to account for non centrality.

Table 2.2: Diagnostics for Spatial Dependence for Variation (2) $\ln$ Pat $_{i}=\alpha_{0}+\alpha_{1} \ln \left(R D_{f}\right)_{i}+\alpha_{2} \ln \left(R D_{u}\right)_{i}+\alpha_{4} \ln \left(L_{f}\right)_{i}+\alpha_{5} \ln \left(L_{u}\right)_{i}+u_{2}$

\begin{tabular}{|lllll|}
\hline Test & Weight & MI/DF & Value & P-value \\
\hline Moran's I & PAT45 & 0.027666 & 0.781934 & 0.000156 \\
\hline $\begin{array}{l}\text { Lagrange } \\
\text { Multiplier }\end{array}$ & PAT45 & 1 & 3.623088 & 0.056983 \\
\hline
\end{tabular}




\begin{tabular}{|c|c|c|c|c|}
\hline (error) & & & & \\
\hline $\begin{array}{l}\text { Robust } \quad \text { LM } \\
\text { (error) }\end{array}$ & PAT45 & 1 & 0.024152 & 0.876499 \\
\hline $\begin{array}{l}\text { Lagrange } \\
\text { Multiplier (lag) }\end{array}$ & PAT45 & 1 & 20.290066 & 0.000007 \\
\hline $\begin{array}{l}\text { Robust } \quad \text { LM } \\
\text { (lag) }\end{array}$ & PAT45 & 1 & 16.691130 & 0.000044 \\
\hline Moran's I & PAT16 & 0.131405 & 0.629486 & 0.000004 \\
\hline $\begin{array}{l}\text { Lagrange } \\
\text { Multiplier } \\
\text { (error) }\end{array}$ & PAT16 & 1 & 14.873417 & 0.000115 \\
\hline $\begin{array}{l}\text { Robust } \quad \text { LM } \\
\text { (error) }\end{array}$ & PAT16 & 1 & 1.072325 & 0.300421 \\
\hline $\begin{array}{l}\text { Lagrange } \\
\text { Multiplier (lag) }\end{array}$ & PAT16 & 1 & 36.338176 & 0.000000 \\
\hline $\begin{array}{l}\text { Robust } \quad \text { LM } \\
\text { (lag) }\end{array}$ & PAT16 & 1 & 22.537085 & 0.000002 \\
\hline Moran's I & NEIG4 & 0.198671 & 0.130463 & 0.000036 \\
\hline $\begin{array}{l}\text { Lagrange } \\
\text { Multiplier } \\
\text { (error) }\end{array}$ & NEIG4 & 1 & 14.023835 & 0.000181 \\
\hline $\begin{array}{l}\text { Robust } \quad \text { LM } \\
\text { (error) }\end{array}$ & NEIG4 & 1 & 0.094157 & 0.758957 \\
\hline $\begin{array}{l}\text { Lagrange } \\
\text { Multiplier (lag) }\end{array}$ & NEIG4 & 1 & 29.210767 & 0.000000 \\
\hline $\begin{array}{l}\text { Robust } \quad \text { LM } \\
\text { (lag) }\end{array}$ & NEIG4 & 1 & 15.281089 & 0.000093 \\
\hline
\end{tabular}

Note: PAT16 is distance-based contiguity for 60 miles; PAT45 is distance-based contiguity for 450 miles; and NEIG4 is a contiguity matrix based on the 4 nearest 
neighbors. Critical value for LM-Error and LM-Lag is $3.84(\mathrm{P}=0.05)$. LM Error test robust to Lag and LM Lag test robust to error adjust LM $\square$ test statistic to account for non centrality.

Table 2.3: Diagnostics for Spatial Dependence for Variation (3)

$\ln P a t_{i}=\alpha_{0}+\alpha_{1} \ln \left(R D_{f}\right)_{i}+\alpha_{2} \ln \left(R D_{u}\right)_{i}+\alpha_{3} \ln \left(L_{u}\right)_{i}+b_{1} \ln$ trade flows $+u_{3}$

\begin{tabular}{|c|c|c|c|c|}
\hline Test & Weight & MI/DF & Value & P-value \\
\hline Moran's I & PAT45 & 0.008560 & 0.870247 & 0.061450 \\
\hline $\begin{array}{l}\text { Lagrange } \\
\text { Multiplier } \\
\text { (error) }\end{array}$ & PAT45 & 1 & 0.346804 & 0.555928 \\
\hline $\begin{array}{l}\text { Robust LM } \\
\text { (error) }\end{array}$ & PAT45 & 1 & 0.615733 & 0.432637 \\
\hline $\begin{array}{l}\text { Lagrange } \\
\text { Multiplier (lag) }\end{array}$ & PAT45 & 1 & 7.619204 & 0.005775 \\
\hline $\begin{array}{l}\text { Robust LM } \\
\text { (lag }\end{array}$ & PAT45 & 1 & 7.888134 & 0.004976 \\
\hline Moran's I & PAT16 & 0.099984 & 0.828516 & 0.000129 \\
\hline $\begin{array}{l}\text { Lagrange } \\
\text { Multiplier } \\
\text { (error) }\end{array}$ & PAT16 & 1 & 8.610852 & 0.003342 \\
\hline $\begin{array}{l}\text { Robust } \quad \text { LM } \\
\text { (error) }\end{array}$ & PAT16 & 1 & 0.189170 & 0.663608 \\
\hline $\begin{array}{l}\text { Lagrange } \\
\text { Multiplier (lag) }\end{array}$ & PAT16 & 1 & 23.420379 & 0.000001 \\
\hline $\begin{array}{l}\text { Robust LM } \\
\text { (lag) }\end{array}$ & PAT16 & 1 & 14.998697 & 0.000108 \\
\hline
\end{tabular}




\begin{tabular}{|lllll|}
\hline Moran's I & NEIG4 & 0.108062 & 0.491723 & 0.012713 \\
\hline $\begin{array}{l}\text { Lagrange } \\
\text { Multiplier } \\
\text { (error) }\end{array}$ & NEIG4 & 1 & 4.149012 & 0.041659 \\
\hline $\begin{array}{l}\text { Robust } \\
\text { (error) }\end{array}$ & NEIG4 & 1 & 3.340664 & 0.067587 \\
\hline $\begin{array}{l}\text { Lagrange } \\
\text { Multiplier (lag) }\end{array}$ & NEIG4 & 1 & 21.534348 & 0.000003 \\
\hline $\begin{array}{l}\text { Robust LM } \\
\text { (lag) }\end{array}$ & NEIG4 & 1 & 20.726000 & 0.000005 \\
\hline
\end{tabular}

Note: PAT16 is distance-based contiguity for 60 miles; PAT45 is distance-based contiguity for 450 miles; and NEIG4 is a contiguity matrix based on the 4 nearest neighbors. Critical value for LM-Error and LM-Lag is $3.84(\mathrm{P}=0.05)$. LM Error test robust to Lag and LM Lag test robust to error adjust LM $\square$ test statistic to account for non centrality.

Knowledge effects of universities and firms on geographical regions are transmitted via technology transfers: many high technology innovations were originated in research findings at local universities, and the expectation of potential future knowledge transfers from academic institutions has attracted a large number of new companies into those geographical regions. It was the aim of our analysis to evaluate whether knowledge impacts in a region are unique, non-repeatable phenomena, or other regions face similar impacts.

The choice of research approach is justified by the fact that disregarding spatial dependence in econometric models may invalidate research findings. The most developed empirical model, the Griliches-Jaffe Knowledge Production Function approach, provided the analytical framework for modeling university and firms effects in the empirical chapters of this study: the knowledge production function was applied to capture university and firm technology transfers, the influence of labor force and the weight of local characteristics, whereas spatial distribution of research activities and employment were modeled by using R\&D expenditure and number of employees, 
respectively. Moreover, growth rates of technology diffusion were studied using the methodology of spatial econometrics. Such rates are particularly useful in case of policy formulation, since they consist a suitable indicator for detecting regions which need more attention. Table 2.4 summarizes our results. It exhibits each research question we answered and shows the differences of the selected explanatory variables.

Clustering tendencies of these variables were analyzed in order to depict their distribution and association in the area of the USA. Such clusters suggested that knowledge and technology transfers might be significant components not only in certain regions but also in neighboring regions. The major clusters of technological spillovers, R\&D, private and university research, and employment are in the west and east states and some parts of the southern states.

Observing strong patterns of technology diffusion is the result of the interaction among universities and firms. The spatial extent of such interactions has been well established in our analysis. It was shown that knowledge transfers are effective within different distance range around the clustering areas. Technology transfers follow a definite distance decay pattern: this is proven by the fact that both the value of the coefficients of R\&D expenditure from both universities and firms are higher than those of the 'ring' variables (i.e., the variable that represents university research within a certain range of distance from the examined spatial unit). According to our results, this is also the case for the growth rates for the variables under study. The only exception is the growth rate of $R \& D$ expenditure of firms where the 'ring' variable has a higher coefficient than the variable of the spatial unit under study.

Table 2.4: Summary of Research Questions and Variations

\begin{tabular}{|c|c|c|c|c|c|c|}
\hline \multicolumn{3}{|c|}{ Research Question 1} & \multicolumn{3}{|c|}{ Research Question 2} & $\begin{array}{l}\text { Research } \\
\text { Question } 4\end{array}$ \\
\hline \multicolumn{3}{|c|}{$\begin{array}{l}\text { "How do universities and firms } \\
\text { knowledge spillovers contribute } \\
\text { to the creation of new technology } \\
\text { and the diffusion of knowledge in } \\
\text { space?" }\end{array}$} & \multicolumn{3}{|c|}{$\begin{array}{l}\text { "How does the } \\
\text { productivity of patents by } \\
\text { universities is affected by } \\
\text { the R\&D expenditures, } \\
\text { employment of firms and } \\
\text { trade flows?". }\end{array}$} & $\begin{array}{l}\text { "How does the study } \\
\text { of the growth rates of } \\
\text { the variables of an } \\
\text { augmented } \\
\text { knowledge } \\
\text { production function } \\
\text { contribute to policy } \\
\text { formulation?". }\end{array}$ \\
\hline \begin{tabular}{l|l|} 
Variables & $\begin{array}{l}\text { Variatio } \\
\text { n 1 }\end{array}$ \\
\end{tabular} & $\begin{array}{l}\text { Variati } \\
\text { on } 2\end{array}$ & ariati & Variables & & $\begin{array}{l}\text { ariati } \\
5\end{array}$ & \begin{tabular}{|l|l|} 
Variables & $\begin{array}{l}\text { Variati } \\
\text { on 7 }\end{array}$
\end{tabular} \\
\hline
\end{tabular}




\begin{tabular}{|c|c|c|c|c|c|c|c|c|}
\hline Constant & $\begin{array}{l}- \\
1.63 \\
(0.5 \\
1) \\
\end{array}$ & $\begin{array}{l}-1.57 \\
(0.87)\end{array}$ & $\begin{array}{l}-1.74 \\
(0.68)\end{array}$ & Constant & $\begin{array}{l}-5.08 \\
(1.01)\end{array}$ & $\begin{array}{l}3.39 \\
(1.16)\end{array}$ & Constant & $\begin{array}{l}-0.03 \\
(0.01)\end{array}$ \\
\hline $\begin{array}{l}\mathrm{W}_{45} \ln \mathrm{P} \\
\mathrm{AT}\end{array}$ & $\begin{array}{l}0.53 \\
(0.2 \\
1) \\
\end{array}$ & $\begin{array}{l}0.81 \\
(0.19)\end{array}$ & $\begin{array}{l}0.62 \\
(0.19)\end{array}$ & $\begin{array}{l}\mathrm{W}_{45} \_\ln \mathrm{TP} \\
\mathrm{PF}\end{array}$ & & $\begin{array}{l}-0.37 \\
(0.19)\end{array}$ & $\mathrm{W}_{45 \_} \operatorname{lnGP}$ & $\begin{array}{l}-0.06 \\
(0.02)\end{array}$ \\
\hline $\ln \mathrm{RDF}$ & $\begin{array}{l}0.65 \\
(0.0 \\
8)\end{array}$ & $\begin{array}{l}0.49 \\
(0.09)\end{array}$ & $\begin{array}{l}0.61 \\
(0.07)\end{array}$ & $\begin{array}{l}\mathrm{W}_{45} \_\operatorname{lnTP} \\
\mathrm{PU}\end{array}$ & $\begin{array}{l}-0.08 \\
(0.03)\end{array}$ & & $\operatorname{lnGRD}$ & $\begin{array}{l}0.39 \\
(0.02)\end{array}$ \\
\hline $\operatorname{lnRDU}$ & $\begin{array}{l}0.23 \\
(0.0 \\
6)\end{array}$ & $\begin{array}{l}0.17 \\
(0.09)\end{array}$ & $\begin{array}{l}0.22 \\
(0.06)\end{array}$ & $\ln R D F$ & $\begin{array}{l}0.67 \\
(0.08)\end{array}$ & & $\operatorname{lnGRDU}$ & $\begin{array}{l}0.24 \\
(0.04)\end{array}$ \\
\hline $\operatorname{lnLF}$ & & $\begin{array}{l}-0.21 \\
(0.05)\end{array}$ & & $\operatorname{lnRDU}$ & & $\begin{array}{l}0.14 \\
(0.07)\end{array}$ & $\operatorname{lnGEmpF}$ & $\begin{array}{l}0.55 \\
(0.01)\end{array}$ \\
\hline $\operatorname{lnLU}$ & & $\begin{array}{l}-0.24 \\
(0.12)\end{array}$ & $\begin{array}{l}-0.07 \\
(0.04)\end{array}$ & $\operatorname{lnLF}$ & $\begin{array}{l}-0.11 \\
(0.02)\end{array}$ & & $\operatorname{lnGEmpU}$ & $\begin{array}{l}0.64 \\
(0.01)\end{array}$ \\
\hline $\ln \mathrm{HH}$ & & & $\begin{array}{l}0.12 \\
(0.01)\end{array}$ & $\operatorname{lnLU}$ & & $\begin{array}{l}-0.61 \\
(0.07)\end{array}$ & $\begin{array}{l}\text { lnGRtradefl } \\
\text { ows }\end{array}$ & $\begin{array}{l}0.86 \\
(0.02) \\
\end{array}$ \\
\hline \multirow[t]{2}{*}{$\ln E S$} & & & $\begin{array}{l}0.008 \\
(0.00 \\
4)\end{array}$ & $\begin{array}{l}\text { lnTradeflo } \\
\text { ws }\end{array}$ & $\begin{array}{l}0.44 \\
(0.14)\end{array}$ & $\begin{array}{l}0.44 \\
(0.15)\end{array}$ & & \\
\hline & & & & $\operatorname{lnEMPHT~}$ & $\begin{array}{l}-0.31 \\
(0.10) \\
\end{array}$ & $\begin{array}{l}0.13 \\
(0.06) \\
\end{array}$ & & \\
\hline
\end{tabular}

An important aspect of our methodology is based on the introduction of variables that capture the local characteristics of the areas at state level in USA. Such variables shed some light on the population characteristics of each State. For instance, the trade flows provides some intuition about the trade density and also the number of scientists and engineers reveals educational level of those states. Therefore, we are able to draw both quantitative and qualitative conclusions. Their presence in a spatial interactive model allows one to examine the behavior of such variables under the assumption of spatial dependence.

Our analysis points to several broad conclusions. Firstly, bigger market size, rather than lower research productivity, explains USA's higher rate of private research efforts. Secondly, increasing research productivity in most us states, could make a substantial contribution to the diffusion of new knowledge in the entire country. Thirdly, us policy measures to increase research output (i.e., stronger patent protection 
or enhanced research productivity) may support and improve the productivity of new technology. Fourthly, an advantage in implementing research policy at the national level is the significant limitations of free riding, concerning the use of patents.

All these conclusions are drawn from a particular parameterization of a certain framework. Any theoretical framework ignores aspects of the world that are potentially important. Such aspects refer to socio-economic structures that are significant to any study, such as, lack of perfect competition or the existence of externalities.

Finally, it is important to highlight some key results which are derived from the model specification and the level of spatial aggregation:

1. The amount of potential researchers (scientists and engineers) and the volume of trade flows are important parameters which enhance productivity of new technology in USA by facilitating the diffusion of knowledge spillovers across the States.

2. There is a large variance in research intensities across us states. However, the magnitude of the variance is projected to become smaller due to the significant number of research projects which are expected to be funded in less developed states.

3. States with higher level of research expenditure per given amount of labor force and a higher rate of patenting are the states with a higher research intensity.

4. Research and Development (R\&D) inputs are measured (and also modeled) as labor and investment inputs. Now, had R\&D been modeled as embodying both labor and capital, its role and interpretation might have been significantly different.

In terms of policy formulation, the basic picture that emerges is that productivity of patents in USA is very responsive and sensitive to various elements of social and economic environment (such as number of researchers or population). Such factors may be the input of any development plan for the US states. Thus, our methodology try to provide the effect of a variety of factors such as employment, number of scientists and engineers or number of households which is an indirect measure of population. The discussed results are based on the suggested modeling. However, a number of variables may be used to alter our modeling in order to account 
for different characteristics of the local economies. Such variables are the size of firms, the existence of metropolitan areas, and Gross Domestic Product (GDP).

\subsection{European Union and United States of America: A Comparison}

Despite the substantial variations in research designs in both European Union and United States of America, findings regarding knowledge transfers and technology diffusion are stable across studies: new knowledge is significantly determined by both the local and neighboring areas of its creation. However, different approaches were used in both the above areas.

Table 2.5 demonstrates that different studies, which use knowledge production function, exhibit substantial differences regarding their methodology and the choice of spatial units. University knowledge transfers were first modeled by the knowledge production function in Jaffe (1989). In his study, economically useful new knowledge was proxied by the number of patents, while private and university $R \& D$ expenditures measured private and university research activities, respectively. However, his research design employs US States which is not the lowest level of spatial aggregation. On the other hand, Varga (1998) used metropolitan statistical areas (MSAs) which is a more appropriate unit of geographical aggregation since it refers to smaller and more coherent regions. His methodology is designed to account for spatial dependence and his focus is on the spatial distribution of the variables of interest.

Studies conducted for European Union, also, present a variety as far their methodology. Bottazzi and Peri (2003) considered the production of patents in certain areas in European Union. Their modeling approach failed to considered spatial autocorrelation directly and thus spatial dependence was underestimated.

Table 2.5: A Comparison of the Literature for Knowledge Spillovers between EU and US

\begin{tabular}{|c|c|c|c|c|c|}
\hline \multirow{4}{*}{$\begin{array}{l}\text { Geographical } \\
\text { regions }\end{array}$} & \multicolumn{2}{|c|}{ United States of America } & \multicolumn{3}{|c|}{ European Union } \\
\hline & $\begin{array}{l}\text { Jaffe } \\
\text { (1989) }\end{array}$ & $\begin{array}{l}\text { Varga } \\
(1998)\end{array}$ & $\begin{array}{l}\text { Psachoulias } \\
(2021)\end{array}$ & $\begin{array}{l}\text { Bottazzi and } \\
\text { Peri (2003) }\end{array}$ & $\begin{array}{l}\text { Karkalakos } \\
(2004)\end{array}$ \\
\hline & 29 States & $\begin{array}{l}125 \\
\text { metropolitan } \\
\text { statistical areas }\end{array}$ & 50 States & 86 regions & 157 regions \\
\hline & OLS, 3SLS & Maximum & Maximum & Weighted IV & Maximum \\
\hline
\end{tabular}




\begin{tabular}{|c|c|c|c|c|c|}
\hline Method & & Likelihood & Likelihood & & Likelihood \\
\hline $\begin{array}{l}\text { Dependent } \\
\text { variable }\end{array}$ & $\begin{array}{l}\text { Log of } \\
\text { corporate } \\
\text { patents by } \\
\text { state }\end{array}$ & $\begin{array}{l}\text { Log of } \\
\text { innovations by } \\
\text { area }\end{array}$ & $\begin{array}{l}\text { Log of patents } \\
\text { by state }\end{array}$ & $\begin{array}{l}\text { Log of } \\
\text { patents by } \\
\text { region }\end{array}$ & $\begin{array}{l}\text { Log of patents } \\
\text { by region }\end{array}$ \\
\hline $\begin{array}{l}\text { Other } \\
\text { independent } \\
\text { variables }\end{array}$ & $\begin{array}{c}-\log (\text { industry } \\
\text { R\&D) } \\
\text { - } \log (\text { population })\end{array}$ & $\begin{array}{l}\text { Log(employment } \\
\text { in high tech } \\
\text { sectors) } \\
\text { - } \\
\text { Log(employment } \\
\text { in business } \\
\text { services) } \\
\text {-Log(percentage } \\
\quad \text { of large } \\
\quad \text { firms) }\end{array}$ & $\begin{array}{l}\text { - } \log (\text { industry } \\
\text { R\&D) } \\
-\log (\text { trade flows }) \\
-\log (\text { human } \\
\quad \text { capital })\end{array}$ & $\begin{array}{l}\text { - } \log \text { (measure } \\
\text { of intensity } \\
\text { of } \\
\text { spillovers) }\end{array}$ & $\begin{array}{l}\text {-Log(households } \\
\text { - } \log \text { (scientists } \\
\text { and } \\
\text { engineers) }\end{array}$ \\
\hline $\begin{array}{l}\text { Tests for } \\
\text { spatial } \\
\text { dependence }\end{array}$ & No & Yes & Yes & No & Yes \\
\hline Result & $\begin{array}{l}\text { The } \\
\text { relationship } \\
\text { between } \\
\text { patents and } \\
\text { R\&D activities } \\
\text { is interpreted as } \\
\text { the proof of the } \\
\text { existence of } \\
\text { "technological } \\
\text { spillovers". } \\
\text { Location is } \\
\text { important as far } \\
\text { as innovation } \\
\text { performance. }\end{array}$ & $\begin{array}{l}\text { University } \\
\text { research follows } \\
\text { similar } \\
\text { clustering } \\
\text { patterns as } \\
\text { innovations and } \\
\text { industrial R\&D. }\end{array}$ & $\begin{array}{l}\text { Knowledge } \\
\text { spillovers depend } \\
\text { on research } \\
\text { externalities, } \\
\text { trade flows and } \\
\text { on elasticity of } \\
\text { human capital } \\
\text { with respect to } \\
\text { patents, which } \\
\text { plays an } \\
\text { important role as } \\
\text { far as } \\
\text { productivity of } \\
\text { new technology. }\end{array}$ & $\begin{array}{l}\text { Knowledge } \\
\text { spillovers } \\
\text { depend on } \\
\text { research } \\
\text { externalities } \\
\text { and they are } \\
\text { very localized } \\
\text { as they exist } \\
\text { only up to } \\
\text { distance of } \\
300 \mathrm{Km}\end{array}$ & $\begin{array}{l}\text { Knowledge } \\
\text { spillovers } \\
\text { depend on } \\
\text { research } \\
\text { externalities } \\
\text { and on } \\
\text { elasticity of } \\
\text { employment } \\
\text { with respect to } \\
\text { patents, which } \\
\text { plays an } \\
\text { important role } \\
\text { as far as } \\
\text { productivity of } \\
\text { new } \\
\text { technology. }\end{array}$ \\
\hline
\end{tabular}

Note: The measurement units of the above variables may vary among different authors.

The choice of the geographical areas of the above studies was based on the availability of data and thus significant parts of Europe were not included in the analysis.

The novel element of our analysis is consisted of two parts. Firstly, the employment of a spatial econometric framework which is suitable for the purposes of our research (Technological diffusion in USA). Such a framework allows one to explore the spatial structure of our data and formulate conclusions on the basis of well established results. Secondly, the inclusion, in the knowledge production function, of the elasticities of labor in universities and firms, trade flows and scientific human 
capital provide a different perspective to the existing literature. Thus, any policy plan for technological development may be based not only on the behavior of R\&D expenditures but also on the contribution of the labor force in firms and universities. Furthermore, the study of growth rates of the variables of interest allows one to track the rate of technological convergence throughout the US States. 


\section{Chapter 3 \\ Growth and Technology Production: \\ Conglomerative Effects}

\subsection{Introduction}

Economic growth and development is primarily driven by technological progress (Romer, 1986). Regional economic growth is not based only on the innovation activity carried out locally, but also on the ability to absorb external technological achievements. The related literature, in the use of patent from the knowledge production function, has studied the relationship between homegrown and external accessible R\&D activity; starting with the pioneering works of Scherer (1965) and Mueller (1966).

Empirical results presented differ on econometric approach followed and, moreover, on the level of analysis performed. A common finding is the existence of a strong positive relationship between R\&D and patent production (Pakes and Griliches, 1980; Hausman et al., 1984; Hall et al., 1986; Blundell et al., 2002).

Although the importance of geographic proximity has been strongly emphasized in the knowledge spillover literature, as technological knowledge is highly contextual and requires frequent contacts and interactions to spill over, most of the studies do not explicitly account for alternative types of proximity along with the geographic proximity. For example, the studies of Peri (2005) and Bottazzi and Peri (2007) assess the effect of own R\&D stock along with that of other regions', weighted by the bilateral geographic distance between them, on regional patent production, proving evidence on the importance of external available knowledge.

However, the size of technological knowledge interaction between two countries (regions) also depends on the size of knowledge performed elsewhere. Policies towards innovation inputs and market characteristics formulate the distribution of innovation inputs across space and, therefore, regional interactions. This thesis studies how the spatial concentration of innovation activity shapes the production of innovation in the US states. We augment the standard knowledge production function with a structure that allows for spatial effects and income effects. 
We account not only for bilateral influences, but also for effects from the rest of the states in technology production. In doing so, we avoid overestimating the effect of local and external technological knowledge in producing local technological products.

\subsection{A Two-Generation Model}

The relation between patents and technology production is underlined by the employment of a two-period production model. In the first period, we account for all the states of a country, who, in the second period, will be separated at two categories, the investor's type states [High skilled]- states that make many patents- and the noninvestors type states [Low skilled] - states that do not make patents or make few patents.

At the first period a state is endowed with human capital $h_{f}-$ the whole human capital of the researchers of the state. It derives income from this human capital which allow it to pay for its own expenses and for "investments" it makes in the human capital of its researchers in order to produce patents - become investors type state - at the next period -period two- $h_{p}$. Each investor's type state's additional human capital equals the investments attributed to the state. At the period two it will earn income based on the additional human capital and spend this income on its own expenses, $c_{s}$.

Spillovers are a crucial aspect of the production technology. High skilled states exert a positive influence on the productivity of the others same kind states of the country, and the productivity of lower skilled states of the others same kind states of the country. On the other hand, low skilled states have a negative effect on the productivity of high-skilled. One possibility is a CES aggregate of the human capital of all states in the set I:

$$
y=\left(\int_{i \in I} h_{i}^{\lambda} d i\right)^{\frac{1}{\lambda}}
$$

This production function captures the spillover effects we are interested in, but has the uncomfortable implication that each state is a defacto monopolist. To alleviate this downside, we restrict human capital attainments to be discrete levels contained in the set $\mathrm{H}$. Changing the variable of integration in the above formulation results in the following production function: 


$$
y=\left(\int_{h \in H} q(h) h^{\lambda} d h\right)^{\frac{1}{\lambda}}
$$

where $\mathrm{q}(\mathrm{h})$ is the measure of states from the set I who possess human capital $\mathrm{h}$. Under this representation the patent function $\mathrm{p}(\mathrm{h})$ is as given. The parameter $\lambda \in(0,1]$ dictates the degree of skill substitutability. If $\lambda=1$ then the skills of different states are perfectly substitutable. As $\lambda$ becomes smaller the skills of different states become less substitutable. Lower substitutability of skills implies higher strategic complementarity in skill investments because the productivity of each state increasingly depends on the productivity of other states. This is apparent in the marginal product (patent) of the measure $\mathrm{q}(\mathrm{h})$ :

$$
p(h)=\frac{1}{\lambda} y^{1-\lambda} h^{\lambda}
$$

Others states' productivities influence a state's patents through $\mathrm{y}$, but the influence of $y$ diminishes as $\lambda$ approaches unity.

A state's value function, $\mathrm{V}_{\mathrm{f}}\left(\mathrm{h}_{\mathrm{f}}\right)$, depends on own (both regional and private) expenses and, through technological spillovers, on the utility of the investors type states, $\mathrm{V}_{\mathrm{s}}\left(\mathrm{h}_{\mathrm{s}}\right)$. The degree of technological spillover is equal to $\beta$, hence the state's value function is

$$
V_{f}\left(h_{f}\right)=\max _{e_{f}, h_{s}}\left\{u\left(e_{f}\right)+\beta V_{s}\left(h_{s}\right) \mid e_{f}+h_{s}=p\left(h_{f}\right)\right\}
$$

The constraint in the maximization problem is the state's budget constraint. Its expenses and its investments in its researcher's human capital must be paid for out of labor income of the state. Implicit in this restriction is that states cannot borrow in order to finance human capital.

Given the two period nature of the problem the state's value function at the second period is simply

$$
V_{s}\left(h_{s}\right)=\max _{e_{s}}\left\{u\left(e_{s}\right) \mid e_{s}=p\left(h_{s}\right)\right\}
$$


The constraint is the state's budget identity at the second period. Because this period is the final period, the state has only expenses. The following inter-state equation can be derived from the first-order optimality conditions:

$$
h_{s}^{1-\lambda}=\frac{u^{\prime}\left(e_{s}\right)}{u^{\prime}\left(e_{f}\right)} \beta \lambda y_{s}^{1-\lambda}
$$

This equation obviates the complexity of a state's problem. Their choice of human capital investment in their state is related to their marginal utility of expenses at the first and second period, as well as regional economic conditions. Under the assumption of log-utility a state's human capital, at the second period, can be solved as a function of primitive parameters:

$$
h_{s}=\frac{\beta \lambda}{1+\beta \lambda} y_{f}^{1-\lambda} h_{f}^{\lambda}
$$

This expression has the stark implication that the elasticity of a state's patents, at the second period, with respect to state's patents, at the first period, is directly dependent on the prevailing degree of skill substitutability in the regional economy. A second important implication is that the influence of others' state's skills on one's state's human capital increases as skills become more complementary in production.

\subsection{Empirical Methodology}

\subsubsection{A Spatial Knowledge Production Function}

We begin by describing the technology production of innovation activity in a given state $i$ as it was described in the above framework (equations 1 to 7). Similar to the production of physical goods, the production of new knowledge (innovation), the innovative output, $\mathrm{Q}$, in state $\mathrm{i}$ is determined by the $\mathrm{R} \& \mathrm{D}$ activity in state $\mathrm{i}$ as well as by the human capital of that state and is given by:

$$
Q_{i t}=R D_{i t}^{\lambda} h_{i t}^{\gamma}
$$

where $Q$ is the innovative output in state $i$ at year t, R\&D is 'own' knowledge stock accumulated from past and current $R \& D$ investments in state $i, h$ is state's $i$ 
human capital proxied by the number of scientists in state i. Allowing for spatial and other effects we may define baseline equation (8) which can be expressed as follows:

$$
\mathrm{Q}_{\mathrm{it}}=a+\lambda \mathrm{RD}_{\mathrm{it}}+\gamma \mathrm{h}_{\mathrm{it}}+\rho \mathrm{WQ}_{\mathrm{it}}+\varphi \mathrm{WQ}_{\mathrm{it}-1}+\mu \mathrm{WRD}_{\mathrm{it}}+\delta \mathrm{Wh}_{\mathrm{it}}+e_{\mathrm{it}}
$$

Equation (9) is a log-linearizing model of a spatial knowledge function. Moreover, the hedonic approach to economic assessment can be used for evaluating the output of technological goods that can be considered aggregates of different attributes, some of which, as they cannot be sold separately, do not have an individual price. The basic premise of the hedonic pricing method is that the price of a marketed good is related to its characteristics, or the services it provides. Although technology product characteristics are neither produced nor consumed in isolation, hedonic price models may assume that the price of a patent reflects embodied characteristics valued by some implicit or shadow prices. The above approach attempts to estimate the technological output using implicit characteristics of a regional economy.

The mixed hedonic pricing model has many advantages, including the ability to estimate values, based on concrete choices, particularly when applied to property markets with readily available, accurate data. The method is flexible enough to be adapted to relationships among other market goods and external factors. Finally, the suggested spatial mixed hedonic knowledge production function may be defined as:

$$
\ln \mathrm{Q}_{\mathrm{it}}=a+\rho \mathrm{WQ}_{\mathrm{it}}+\varphi \mathrm{WQ}_{\mathrm{it}-1}+\lambda \mathrm{RD}_{\mathrm{it}}+\xi \text { Netsales }_{\mathrm{it}}+\theta \mathrm{FedRD}_{\mathrm{it}}+v \text { ComRDout }_{\mathrm{it}}
$$
$+e_{\text {it }}$

where Netsales is the net sales at state level, FedRD is the federal expenses of RD and ComRDout accounts for company RD expenses out of USA.

\subsection{Data}

Our empirical analysis is based on a sample of 50 US states (DC is excluded) from 1995 to 2007. Annual data are retrieved from the following sources: Patent and citation data are obtained from the National Bureau of Economics Research (NBER) Patent and Citation Data Project, which is publicly available and described in detail by Hall and Ziedonis (2001). The database contains all utility patents granted by the US patent office since 1975 and all citations to these patents up until 2007. 
Figure 3.1: Number of Patents per State (1995-2007)

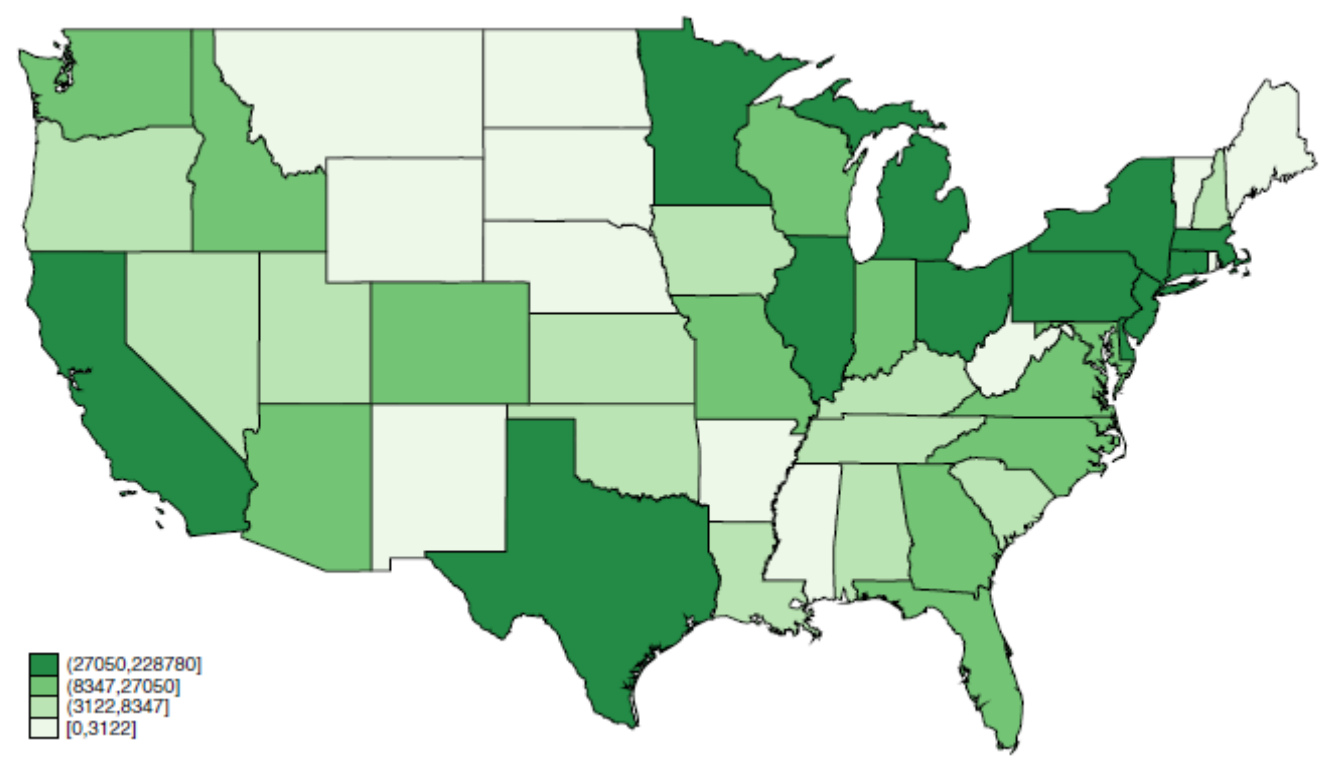

We choose the sample of patents granted between 1995 and 2007 whose assignee is located in the US. Information on the two inputs of knowledge production function, $R \& D$ expenditure (for constructing $R \& D$ capital stocks) and doctoral scientists and engineers devoted to research (for human capital) is extracted from the National Science Foundation Science and Engineering State Profiles. Lastly, the allocation of patents into different technological fields is based on patents' primary US classifications according to the NBER. Patents along with the R\&D expenditures refer to individual industries such as food and tobacco products, chemical and allied products, petroleum and refining products, machinery, electrical equipment, and transportation industry.

\subsection{Econometric Framework}

The standard model can be written as:

$$
Y=X \beta+\varepsilon, \quad(11)
$$

where $\varepsilon$ is assumed to be normally distributed with zero mean and constant variance.

Our analysis of spatial effects addresses three questions. First, are spatial effects present? To answer this question, we compare a model that includes spatial effects to 
one without spatial effects (Bowen, et al., 2001). If evidence of spatial autocorrelation and/or spatial (autoregressive) dependence is found, our reaction function will need to be modeled through the use of spatial statistics (e.g., see Cliff and Ord 1981). For example, spatial autocorrelation may exist when omitted unobservable characteristics. In light of evidence that spatial effects exist, then we attempt to answer a second question. What is the preferred estimation model? To answer this question, we make a series of pairwise comparisons between different spatial effects models. Finally, because we find evidence of spatial autocorrelation, we must also answer the following question: Which estimation approach - maximum likelihood or generalized moments is more appropriate? The existence of spatial autocorrelation increases the possibility that the errors will not be the distributed normally. Maximum likelihood estimation of the spatial autocorrelation coefficient depends on the assumption of normality of the regression error terms, while the generalized moments approach does not.

A general spatial econometric model can be written by incorporating a spatial error process as well as a spatially lagged dependent variable, modifying equation (1) as follows:

$$
\begin{array}{r}
Y=\rho W Y+X \beta+\varepsilon, \\
\varepsilon=\lambda W \varepsilon+\mu,
\end{array}
$$

where $\mu$ is distributed normal with zero mean and constant variance and $\mathrm{W}$ is an $\mathrm{N}$ by $\mathrm{N}$ weight matrix (Kelejian \& Prucha, 2007). In scalar notation, the weight that an individual house (j) has on house i's sale price is equal to

$\mathrm{w}_{\mathrm{ij}}=1 / \mathrm{d}_{\mathrm{i}, \mathrm{j}}, \mathrm{i}, \mathrm{j}=1,2, \ldots, \ldots$

$=0, \quad \mathrm{i}=\mathrm{j}$,

where $d_{i, j}$ is the Euclidean distance between house $i$ and $j$. These weights are "row normalized" so that

$$
\sum_{j} w_{i, j}=1, i, j=1,2 \ldots, \ldots
$$


When $\lambda$ and $\rho$ are equal to zero, what remains is the standard model of equation (11) that we estimated by ordinary least squares. Examination about the existence of spatial effects requires that we first compare the model in equation (11) with the following model:

$$
\begin{gathered}
Y=X \beta+\varepsilon,(13) \\
\varepsilon=\lambda W \varepsilon+\mu
\end{gathered}
$$

where $\mu$ is an error term that is distributed normal with zero mean and constant variance, and $\mathrm{W}$ is as described above. Specifically, we test for the presence of spatial autocorrelation in this model (i.e. the significance of $\lambda$ ) with the Moran I test, the Likelihood Ratio (LR) test, and the Wald test.

Next, we proceed to test the significance of including the spatial autoregressive parameter $\rho$ in this spatial error model. In other words, we test model (13) against model (12) as described above. We would expect the sign of the coefficient on the spatially lagged dependent variable $(\rho)$ to be positive. This implies the presence of positive adjacency effects. Thus, another objective of this study is to test for the sign and magnitude of such adjacency effects through the spatial autoregressive parameter $\rho$. Using the spatial error model as a baseline, we test whether we can reject the hypothesis that this baseline is the "true" model, in favor of the alternative of the spatial autoregressive model with spatial errors.

Finally, we will conduct a Jarque-Bera test for normality of the residuals resulting from the maximum likelihood estimation of the General Spatial Model because the maximum likelihood estimation of the General Spatial Model assumes normality of the errors while the generalized moments technique does not.

In order to focus attention on some additional issues pertaining to interpretation, we follow the approach of Kim, Philipps and Anselin (Kim, et al., 2003) to analyze the impact of a spatial multiplier on marginal benefits of less noise. First, we re-write the estimation equation (i.e., equation(12)) in an analogous form to equation (13) as:

$$
\begin{gathered}
Y=[I-\rho W]^{-1} X \beta+\varphi, \quad(14) \\
\text { where } \varphi=[1-\rho W]^{-1} \varepsilon
\end{gathered}
$$


or in scalar notation,

$$
Y_{i}=\left[1 /\left(1-\rho \sum_{j} w_{i, j}\right)\right] \sum_{k} \beta_{k} X_{k, i}+\varphi_{i}, \quad\left(14^{\prime}\right)
$$

where $\mathrm{i}, \mathrm{j}=1,2, \ldots, \ldots, \mathrm{k}=1,2, \ldots, \ldots$ (the number or explanatory including a column of ones), and

$$
\varphi_{i}=\left[1 /\left(1-\rho \sum_{j} \beta_{k} w_{i, j}\right)\right] \varepsilon_{\imath}
$$

Since the rows of $\mathrm{W}$ sum to 1 , equation (14') can be re-written as:

$$
\begin{gathered}
Y_{i}=\left[\frac{1}{1-\rho}\right] \sum_{k} \beta_{k} X_{k, i}+\varphi_{i} \quad(15), \\
\text { where } \varphi=\left[\frac{1}{1-\rho}\right] \varepsilon_{i}
\end{gathered}
$$

Thus, $[1 /(1-\rho)]$ can be thought of as a spatial multiplier that describes the impact on $\mathrm{Y}_{\mathrm{i}}$ if a unit change were induced at every location and these effects are considered to be induced.

\subsection{Empirical Specification}

Typically in the literature, innovation output of a region is determined by the homegrown technological knowledge of the region as well as by the external, but accessible (or 'borrowed') to the region technological knowledge of other regions (Griliches, 1992; Cohen and Levinthal, 1989). In its simple form, the production function of innovation of a region can be expressed as follows:

$$
Q_{i t}=\left(A_{i t}\right)^{\gamma}\left(A_{i t}{ }^{\alpha}\right)^{\mu}
$$

where $Q$ is the innovative output, proxied by the number of patents produced in country $i$ at time $t ; A$ is own, homegrown knowledge stock, proxied by R\&D stock accumulated from past and current R\&D investments in country $i$; and $A^{\alpha}$ is the stock of external and accessible (hence the $a$ superscript) to country $i$ knowledge stock, proxied by R\&D accumulated in countries other than country $i$. 
Knowledge flows take place when an idea, generated in region, country or institution, is learned by another region, country or institution. If knowledge flows manage to perfectly and completely spill over, then the amount of external knowledge that eventually reaches country $i$ is simply the summation of all borrowed knowledge that comes from all other countries. In reality, however, the diffusion of knowledge flows across states may be less than complete; only a share of research results from other countries reaches country $i$. The external accessible to country i R\&D activity can be described by:

$$
A_{i t}{ }^{\alpha}=\sum_{j \neq i} f_{i j} A_{j t}
$$

Where $f_{i j}$ is the share of knowledge learned in country $i$ originated in country $j$.

Substituting equation (2) into equation (1) and by taking logs, equation (1) yields:

$$
\ln Q_{i t}=\gamma \ln A_{i t}+\mu \ln \sum_{j \neq i} f_{i j} A_{j t}
$$

Foreign R\&D stock for country $i$ and year $t$ that reaches country $i$ via different channels, (i.e., trade of goods, FDI and inventor mobility) and conventionally is constructed as:

$$
R \& D_{i t}^{f}=\sum_{i \neq j}\left(w_{i j, t}^{k} R \& D_{j, t}^{d}\right)
$$

where the weighting scheme $w_{i j, t}^{k}$ is calculated in the empirical literature(Lichtenberg and de la Potterie, 1998; Coe and Helpmann, 1999; Lee, 2005; Coe et al, 2008; Seck, 2012) trade-weighted (if the channel is trade), FDI-weighted (if the channel is FDIand inventor-weighted (of the channel is the mobility of inventors) bilateral flows. We include all three channels in the estimations in order to avoid the omitted variable bias. The chosen baseline specification is the following ${ }^{7}$ :

\footnotetext{
${ }^{7}$ This specification is known in the spatial econometric literature as the Spatially Lagged X (SLX) model since we do not spatially weigh the dependent variable on the right-hand side but rather we employ weights to an independent variable (here, foreign R\&D stock). It needs to be underscored that in all of our models the matrix is economic or technological in the sense that it encompasses relationships based on bilateral trade, investment and inventor flows rather than physical distance.
} 


$$
F_{i t}=a^{D} \ln R D_{i t}^{D}+\sum_{j=1}^{3} a_{j}^{F} \ln R D_{i j t}^{F}+\gamma I_{i t}+\sum_{j=1}^{3} \delta_{j} \ln R D_{i j t}^{F} * I_{i t}+\alpha_{l}+u_{i t}
$$

where $F$ is number of patents, $a_{i}$ are country fixed effects and $\mathrm{I}_{\mathrm{it}}$ is the chosen institutional variable in each specification, which is used both as a stand-alone variable and as an interaction term with each of the three measures of foreign knowledge. The parameter of focus for cross-border spillovers is $\mathrm{a}^{\mathrm{f}}$, a positive value of which validates the claim that the economy benefits from R\&D activities taking place abroad

Foreign knowledge that reach a country would be more effective in shaping local innovation activity once one accounts for absorptive capacity of a country. We include the quality of institutions of a country as measured by the country scores in the Worldwide Governance Indicators (WGI), as they can affect a country's long run growth (Mauro, 1995; Hall and Jones, 1999; Robinson et al., 2005). ${ }^{8}$ In addition, a solid institutional framework and the creation of a supportive eco-system through which firms can acquire and commercialize external knowledge constitute a high degree of domestic absorptive capacity (Crescenzi \& Gagliardi, 2018; Coe et al, 2008; Le, 2010). This effect is tested through the inclusion of the interaction of the foreign knowledge stock with institutional variables that cover important traits of the domestic economy.

Empirical studies have relied in the inclusion of country-fixed effects (Aitken \& Harisson, 1999; Javorcik \& Spatanearu, 2008; Blalock \& Gertler, 2009), however Keller (2009) argues that only some form of instrumental variables estimation could solve the endogeneity problem. Having said that, many studies try to overcome this issue by using a finite number of lagged values of the foreign knowledge stock

\footnotetext{
${ }^{8}$ The broad relationship between institutions and growth manifests itself through various channels. To name a few, poor institutions and corruption reduce foreign direct investment (Javorcik and Wei, 2009) and undermine incentives for domestic firms to reinvest their earnings (Cull and $\mathrm{Xu}$, 2005), with negative implications for growth. Corruption also is found to be related with low attraction and attainment of talented human capital (OECD, 2016). A difficult business environment impedes the entry of new firms to the market (Bruno et al., 2011), which is in turn an important driver of overall productivity growth. In countries with stronger contract enforcement, industries that rely on customized inputs and relation-specific investments grow faster (Nunn, 2007) as better contract enforcement facilitates the necessary investment. Countries with better economic institutions also specialize in more complex production processes in terms of number of various inputs required (Levchenko, 2007). More sophisticated exports can in turn be linked to better growth performance over the long-run (Hausmann et al., 2007).
} 
variable (Branstetter, 2001; Chang et al, 2012; Drivas et al., 2013). We use the same strategy in our initial estimations, however postulate that the construction of an exogenous weighting matrix is more appropriate.

In particular, we assume that $w_{i j} \propto e^{-\theta d} i j$, where $\mathrm{d}_{\mathrm{ij}}$ is economic distance between countries $i$ and $j$ and $\theta$ is an unknown parameter. Each variant has been estimated in the following way. Firstly, consistent estimates of the parameters are obtained using non-linear regression methodology, with a bound on the parameter space that imposes a positive value for the exponential decay parameter $\theta$ (note that this parameter enters with a negative sign in the econometric model). A negative (zero) value of the parameter would imply that characteristics of a region have a bigger spillover effect the further away they are (are independent of economic distance). Hence, this parameter is, or should be, positive for meaningful economic effects. For the same reason, a test of whether $\theta$ is different than zero is not meaningful. Therefore, standard errors are obtained via bootstrapping based on our estimation routine and, by construction, the confidence intervals do not include zero. Asymptotic standard errors, being symmetric in nature, could possibly use confidence intervals that cover zero. This would formally lead to the implication that one cannot reject the hypothesis that the exponential parameter is zero or of the wrong sign, a conclusion that would simply be an artefact of the way symmetric standard errors are computed. The bootstrap standard errors do not suffer from this weakness, but they are asymmetric as a result.

\subsection{Results}

Tables 3.1 and 3.2 present a spatial baseline model at industry state level using geographic and economic weights. The dependent variable is the number of patents and independent variables include research and development expenditures -RDHuman Capital which is defined as the absolute difference between the human capital of the individual state and the average value of all low skilled states. Moreover, a number of neighboring values are included as independent variables, following the suggestions of the literature. 
Table 3.1: Spatial Baseline Model at an Industry Level using Geographic Weights

\begin{tabular}{|c|c|c|c|c|c|c|}
\hline Variable & $\begin{array}{c}\text { Food and } \\
\text { Tabaco }\end{array}$ & $\begin{array}{l}\text { Chemical } \\
\text { and } \\
\text { allied } \\
\text { products }\end{array}$ & $\begin{array}{l}\text { Petroleum } \\
\text { and } \\
\text { refining } \\
\text { products }\end{array}$ & Machinery & $\begin{array}{l}\text { Electrical } \\
\text { equipment }\end{array}$ & $\begin{array}{c}\text { Transportation } \\
\text { Industry }\end{array}$ \\
\hline Constant & $\begin{array}{l}0.48 * * \\
(3.16)\end{array}$ & $\begin{array}{l}0.57^{*} \\
(1.99)\end{array}$ & $\begin{array}{l}0.75^{*} \\
(2.32)\end{array}$ & $\begin{array}{l}0.75^{* *} \\
(2.89)\end{array}$ & $\begin{array}{l}0.63 * * \\
(3.07)\end{array}$ & $\begin{array}{l}0.58 * * \\
(3.11)\end{array}$ \\
\hline $\mathrm{RD}_{\text {it }}$ & $\begin{array}{l}0.71^{*} \\
(1.89)\end{array}$ & $\begin{array}{l}0.48^{*} \\
(1.76)\end{array}$ & $\begin{array}{l}0.76^{*} \\
(1.99)\end{array}$ & $\begin{array}{l}0.88^{*} \\
(1.96)\end{array}$ & $\begin{array}{l}0.95^{*} \\
(2.02)\end{array}$ & $\begin{array}{l}0.45^{*} \\
(2.21)\end{array}$ \\
\hline $\begin{array}{c}\text { Human } \\
\text { Capital }\left(\mathrm{h}_{\mathrm{it}}\right)\end{array}$ & $\begin{array}{l}0.31^{*} \\
(2.16)\end{array}$ & $\begin{array}{l}0.25^{*} \\
(2.09)\end{array}$ & $\begin{array}{l}0.21 * \\
(1.84)\end{array}$ & $\begin{array}{l}0.38^{*} \\
(1.86)\end{array}$ & $\begin{array}{l}0.18^{*} \\
(1.65)\end{array}$ & $\begin{array}{l}0.15^{*} \\
(2.03)\end{array}$ \\
\hline $\begin{array}{c}\text { Neighboring } \\
\text { Patents } \\
\left(\rho \mathrm{WQ}_{\mathrm{it}}\right)\end{array}$ & $\begin{array}{l}0.18^{*} \\
(1.75)\end{array}$ & $\begin{array}{l}0.14^{*} \\
(2.17)\end{array}$ & $\begin{array}{c}0.04 \\
(0.99)\end{array}$ & $\begin{array}{l}0.21^{*} \\
(2.09)\end{array}$ & $\begin{array}{c}0.78 \\
(0.57)\end{array}$ & $\begin{array}{c}0.63 \\
(0.49)\end{array}$ \\
\hline $\begin{array}{c}\text { Temporal lag } \\
\text { of } \\
\text { Neighboring } \\
\text { Patents } \\
\left(\rho \mathrm{WQ}_{\text {it- }-1}\right)\end{array}$ & $\begin{array}{c}0.03 \\
(0.14)\end{array}$ & $\begin{array}{c}0.02 \\
(1.01)\end{array}$ & $\begin{array}{l}0.05 \\
(0.11)\end{array}$ & $\begin{array}{l}0.04 \\
(1.19)\end{array}$ & $\begin{array}{c}0.03 \\
(0.04)\end{array}$ & $\begin{array}{c}0.06 \\
(1.08)\end{array}$ \\
\hline $\begin{array}{c}\text { Neighboring } \\
\text { RD } \\
\left(\mu \mathrm{WRD}_{\mathrm{it}}\right)\end{array}$ & $\begin{array}{l}0.08^{*} \\
(1.92)\end{array}$ & $\begin{array}{l}0.12^{*} \\
(1.88)\end{array}$ & $\begin{array}{l}0.19^{*} \\
(1.71)\end{array}$ & $\begin{array}{l}0.21^{*} \\
(0.87)\end{array}$ & $\begin{array}{l}0.16^{*} \\
(1.89)\end{array}$ & $\begin{array}{c}0.03 \\
(1.18)\end{array}$ \\
\hline $\begin{array}{c}\text { Neighboring } \\
\text { Human } \\
\text { Capital } \\
\left(\delta \mathrm{Wh}_{\mathrm{it}}\right)\end{array}$ & $\begin{array}{c}0.14 \\
(0.78)\end{array}$ & $\begin{array}{l}0.12 \\
(1.18)\end{array}$ & $\begin{array}{c}0.11 \\
(0.51)\end{array}$ & $\begin{array}{c}0.17 \\
(0.77)\end{array}$ & $\begin{array}{c}0.18 \\
(0.59)\end{array}$ & $\begin{array}{c}0.25 \\
(1.02)\end{array}$ \\
\hline Time effects & Yes & yes & yes & yes & yes & yes \\
\hline $\mathrm{R}^{2}$ & 0.67 & 0.58 & 0.59 & 0.71 & 0.68 & 0.55 \\
\hline
\end{tabular}

All columns report maximum likelihood (ML) estimates with spatial error dependence and time effects. Numbers in parentheses are t-values. $(* *)$ and $(*)$ : significance at $5 \%$ and $10 \%$ level, respectively. The element, $\mathrm{w}_{\mathrm{ij}}$ equals to the inverse of squared distance between state I and state, $\mathrm{j}$. 
Table 3.2: Spatial Baseline Model at an Industry Level using Economic Weights (State Income)

\begin{tabular}{|c|c|c|c|c|c|c|}
\hline Variable & $\begin{array}{c}\text { Food and } \\
\text { Tabaco }\end{array}$ & $\begin{array}{l}\text { Chemical } \\
\text { and } \\
\text { allied } \\
\text { products }\end{array}$ & $\begin{array}{l}\text { Petroleum } \\
\text { and } \\
\text { refining } \\
\text { products }\end{array}$ & Machinery & $\begin{array}{l}\text { Electrical } \\
\text { equipment }\end{array}$ & $\begin{array}{c}\text { Transportation } \\
\text { Industry }\end{array}$ \\
\hline Constant & $\begin{array}{l}0.88^{*} \\
(2.15)\end{array}$ & $\begin{array}{l}0.97 * \\
(1.91)\end{array}$ & $\begin{array}{l}0.85^{*} \\
(2.02)\end{array}$ & $\begin{array}{l}1.05 * * \\
(2.97)\end{array}$ & $\begin{array}{l}0.93 * * \\
(3.45)\end{array}$ & $\begin{array}{l}0.98 * * \\
(3.89)\end{array}$ \\
\hline $\mathrm{RD}_{\mathrm{it}}$ & $\begin{array}{l}0.75^{*} \\
(1.98)\end{array}$ & $\begin{array}{l}0.53^{*} \\
(1.94)\end{array}$ & $\begin{array}{l}0.69^{*} \\
(1.73)\end{array}$ & $\begin{array}{l}0.81^{*} \\
(1.71)\end{array}$ & $\begin{array}{l}0.84 * \\
(2.15)\end{array}$ & $\begin{array}{l}0.34 * \\
(1.91)\end{array}$ \\
\hline $\begin{array}{c}\text { Human } \\
\text { Capital }\left(\mathrm{h}_{\mathrm{it}}\right)\end{array}$ & $\begin{array}{l}0.23 * \\
(2.11)\end{array}$ & $\begin{array}{l}0.29 * \\
(2.01)\end{array}$ & $\begin{array}{l}0.24 * \\
(1.89)\end{array}$ & $\begin{array}{l}0.31 * \\
(1.97)\end{array}$ & $\begin{array}{l}0.27^{*} \\
(1.93)\end{array}$ & $\begin{array}{l}0.19^{*} \\
(2.17)\end{array}$ \\
\hline $\begin{array}{c}\text { Neighboring } \\
\text { Patents } \\
\left(\rho \mathrm{WQ}_{\text {it }}\right)\end{array}$ & $\begin{array}{l}0.45^{*} \\
(1.92)\end{array}$ & $\begin{array}{l}0.27 * \\
(2.39)\end{array}$ & $\begin{array}{l}0.01 \\
(0.99)\end{array}$ & $\begin{array}{c}0.07 \\
(1.03)\end{array}$ & $\begin{array}{l}0.52 * \\
(2.57)\end{array}$ & $\begin{array}{c}0.11 \\
(0.03)\end{array}$ \\
\hline $\begin{array}{c}\text { Temporal lag } \\
\text { of } \\
\text { Neighboring } \\
\text { Patents } \\
\left(\rho \mathrm{WQ} \mathrm{Q}_{\mathrm{it}-1}\right)\end{array}$ & $\begin{array}{l}0.12 * \\
(2.14)\end{array}$ & $\begin{array}{l}0.14^{*} \\
(1.78)\end{array}$ & $\begin{array}{l}0.11^{*} \\
(2.19)\end{array}$ & $\begin{array}{l}0.15^{*} \\
(2.38)\end{array}$ & $\begin{array}{l}0.13^{*} \\
(2.03)\end{array}$ & $\begin{array}{c}0.06 \\
(0.67)\end{array}$ \\
\hline $\begin{array}{c}\text { Neighboring } \\
\text { RD } \\
\left(\mu \mathrm{WRD}_{\mathrm{it}}\right)\end{array}$ & $\begin{array}{l}0.17 * \\
(1.73)\end{array}$ & $\begin{array}{l}0.14 * \\
(1.79)\end{array}$ & $\begin{array}{l}0.21 * \\
(1.99)\end{array}$ & $\begin{array}{l}0.27^{*} \\
(1.87)\end{array}$ & $\begin{array}{l}0.14 * \\
(1.93)\end{array}$ & $\begin{array}{c}0.01 \\
(0.15)\end{array}$ \\
\hline $\begin{array}{c}\text { Neighboring } \\
\text { Human } \\
\text { Capital } \\
\left(\delta \mathrm{Wh}_{\mathrm{it}}\right)\end{array}$ & $\begin{array}{c}0.18 \\
(0.79)\end{array}$ & $\begin{array}{c}0.11 \\
(1.01)\end{array}$ & $\begin{array}{c}0.19 \\
(0.88)\end{array}$ & $\begin{array}{c}0.22 \\
(0.94)\end{array}$ & $\begin{array}{c}0.08 \\
(0.28)\end{array}$ & $\begin{array}{c}0.02 \\
(0.17)\end{array}$ \\
\hline Time effects & yes & yes & yes & yes & yes & Yes \\
\hline $\mathrm{R}^{2}$ & 0.69 & 0.62 & 0.64 & 0.73 & 0.67 & 0.52 \\
\hline
\end{tabular}

All columns report maximum likelihood (ML) estimates with spatial error dependence and time effects. Numbers in parentheses are t-values. $(* *)$ and $(*)$ : significance at $5 \%$ and $10 \%$ level, respectively. The element, $w_{\mathrm{ij}}$ equals to the inverse of squared distance between state I and state, $\mathrm{j}$.

Table 3.3 presents estimates of equation (10). The baseline estimation including all potential channels of knowledge diffusion is reported in column (1), while the issue of absorptive capacity is addressed in columns (2) to (4) which include 
interactions with institutional indicator variables.

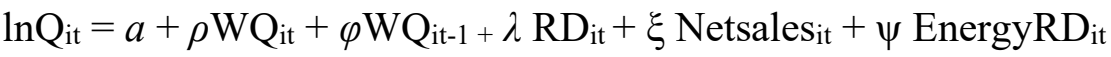

$$
\begin{aligned}
& +\theta \text { FedRD }_{i t}+v \text { ComRDout }_{i t}+e_{i t}
\end{aligned}
$$

Table 3.3: Negative Binomial Geographic Estimates of Innovation Production ${ }^{9}$ (dep. var.: count of patents)

\begin{tabular}{|c|c|c|c|c|}
\hline & \multirow{2}{*}{$\begin{array}{c}\text { Baseline }^{\mathrm{a}} \\
\text { (1) }\end{array}$} & \multicolumn{3}{|c|}{ Institutions $^{\mathbf{b}}$} \\
\hline & & (2) & (3) & (4) \\
\hline \multirow[t]{2}{*}{ R\&Dstock ${ }^{\mathrm{D}}$} & $0.204 * *$ & $0.211 * * *$ & $0.309 * * *$ & $0.288^{* * *}$ \\
\hline & $(0.000)$ & $(0.000)$ & $(0.000)$ & $(0.000)$ \\
\hline \multirow[t]{2}{*}{ R\&Dstock ${ }_{\text {IMPORTS }}^{\mathrm{F}}$} & $0.098 * * *$ & 0.055 & 0.011 & 0.043 \\
\hline & $(0.008)$ & $(0.199)$ & $(0.956)$ & $(0.873)$ \\
\hline \multirow[t]{2}{*}{ R\&Dstock ${ }^{\mathrm{F}}$ FI } & $0.085 * * *$ & $0.123 * * *$ & $0.096 * * *$ & $0.108 * * *$ \\
\hline & $(0.000)$ & $(0.000)$ & $(0.000)$ & $(0.000)$ \\
\hline \multirow[t]{2}{*}{ R\&Dstock ${ }_{\text {INVENTORS }}^{\mathrm{F}}$} & $0.089 * * *$ & $0.096 * * *$ & $0.075 * * *$ & $0.081 * * *$ \\
\hline & $(0.000)$ & $(0.000)$ & $(0.000)$ & $(0.001)$ \\
\hline \multirow{2}{*}{ Institution } & & $0.672 *$ & $1.991 * * *$ & $1.229 * * *$ \\
\hline & & $(0.071)$ & $(0.000)$ & $(0.000)$ \\
\hline \multirow[t]{2}{*}{ R\&Dstock ${ }^{\mathrm{F}}$ IMPORTS $\mathrm{x}$ Netsales } & & 0.117 & $0.482 * * *$ & $0.398 * * *$ \\
\hline & & $(0.187$ & $(0.002)$ & $(0.001)$ \\
\hline \multirow[t]{2}{*}{ R\&Dstock ${ }^{\mathrm{F}}$ FDI $\mathrm{x}$ FedRD $_{\text {it }}$} & & $0.103 * *$ & $0.134 * * *$ & $0.168^{* * *}$ \\
\hline & & $(0.017)$ & $(0.006)$ & $(0.004)$ \\
\hline \multirow[t]{2}{*}{ R\&Dstock ${ }^{\mathrm{F}}$ INVENTORS $\mathrm{x}$ ComRDout } & & $0.059 *$ & $0.073 * * *$ & $0.064 * * *$ \\
\hline & & $(0.052)$ & $(0.001)$ & $(0.006)$ \\
\hline \multirow[t]{2}{*}{ Constant } & $-1.174 * * *$ & $-0.988 *$ & -0.067 & -0.754 \\
\hline & $(0.008)$ & $(0.071)$ & $(0.842)$ & $(0.645)$ \\
\hline Overall imports effect & & 0.147 & 0.376 & 0.288 \\
\hline Overall FDI effect & & 0.019 & 0.015 & 0.011 \\
\hline Overall inventor mobility effect & & 0.083 & 0.105 & 0.175 \\
\hline Observations & 290 & 290 & 290 & 290 \\
\hline LR Statistic & 203.7 & 237.2 & 212.4 & 288.1 \\
\hline
\end{tabular}

Note: All variables are expressed in logs. All estimations include country and year fixed effects. $R \& D s t o c k^{D}$ is

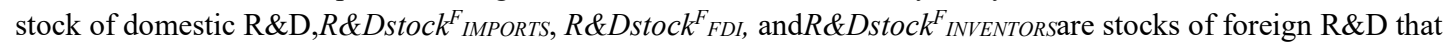
reach a country via the channel of imports (capital goods), FDI and inventor mobility, respectively.

aBaseline estimation in column (1) includes only the effect of domestic and foreign knowledge, proxied by R\&D stocks.

${ }^{\mathbf{b}}$ Institutions estimations in columns (2)-(4) further include the effect of institutions namely, rule of law $(R L)$ in

${ }^{9}$ All estimations include Country Fixed Effects. 
column (2), regulatory quality (RQ) in column (3) and the common factor for all six WGI indicators in column (4). Stars denote significance at the $1 \% * * *, 5 \% * *$ and $10 \% *$ level

$P$ values in Parentheses

Estimates show that not only own knowledge stock (R\&D effort and human capital) matters, but also the co-performances of other states. Patent elasticity with respect to the trade-induced external knowledge flows (the most prominent channel in the analysis) ranges from 0.13 to 0.23 in line with the relevant empirical literature (Coe \& Helpmann, 1999; Lee, 2005; Coe et al., 2008) and is not far from the own R\&D elasticity. Foreign technology accumulated through FDI flows induces a somewhat higher innovative effect than the R\&D stock associated with inventor migration. Moreover, sound governance proves conducive for the positive spillover effect through all three channels examined as can be seen by the statistically significant coefficients of the interaction terms in column (4) which considers the common underlying factor of the six WGI variables available. The LR statistics in all specifications reject the null hypothesis of equi-dispersion, hence validate the use of the Negative Binomial estimator over the Poisson model.

Table 3.4: Results with Economic Weights (dep. var.: count of patents)

\begin{tabular}{|c|c|c|c|c|}
\hline \multirow[t]{2}{*}{ VARIABLES } & \multicolumn{2}{|l|}{ Baseline $^{a}$} & \multicolumn{2}{|c|}{ Institutions ${ }^{b}$} \\
\hline & (1) & (2) & (3) & (4) \\
\hline R\&D Stock ${ }^{\mathrm{D}}$ & $\begin{array}{l}0.306^{*} \\
(0.074)\end{array}$ & $\begin{array}{l}0.254^{*} \\
(0.068)\end{array}$ & $\begin{array}{l}0.224^{*} \\
(0.083)\end{array}$ & $\begin{array}{l}0.311 * \\
(0.096)\end{array}$ \\
\hline R\&D Stock $\mathrm{F}_{\text {Imports }}$ & $\begin{array}{l}0.427 * \\
(0.083)\end{array}$ & $\begin{array}{l}0.117 \\
(0.184)\end{array}$ & $\begin{array}{l}0.389 * \\
(0.089)\end{array}$ & $\begin{array}{l}0.526 * \\
(0.092)\end{array}$ \\
\hline$R \& D$ Stock ${ }_{F D I}$ & $\begin{array}{l}0.089 * \\
(0.067)\end{array}$ & $\begin{array}{l}0.103 * \\
(0.079)\end{array}$ & $\begin{array}{l}0.156^{*} \\
(0.073)\end{array}$ & $\begin{array}{l}0.308 * \\
(0.093)\end{array}$ \\
\hline $\mathrm{R} \& D$ Stock $\mathrm{F}_{\text {Inventors }}^{\mathrm{F}}$ & $\begin{array}{l}0.248 * \\
(0.085)\end{array}$ & $\begin{array}{l}0.367 * * \\
(0.041)\end{array}$ & $\begin{array}{l}0.389^{*} \\
(0.067)\end{array}$ & $\begin{array}{l}0.399 * \\
(0.089)\end{array}$ \\
\hline Institution & & $\begin{array}{l}0.761 * \\
(0.083)\end{array}$ & $\begin{array}{l}0.632 * \\
(0.059)\end{array}$ & $\begin{array}{l}0.832 * \\
(0.062)\end{array}$ \\
\hline
\end{tabular}




\begin{tabular}{|c|c|c|c|c|}
\hline R\&Dstock ${ }^{\mathrm{F}}$ IMPORTS $\mathrm{x}$ Netsales & & $\begin{array}{l}0.845 \\
(0.274)\end{array}$ & $\begin{array}{l}0.995 \\
(0.612)\end{array}$ & $\begin{array}{l}0.843 \\
(0.356)\end{array}$ \\
\hline R\&Dstock $\mathrm{F}_{\text {FDI }} \times$ FedRD $_{\text {it }}$ & & 0.289 & 0.367 & 0.428 \\
\hline & & $(0.587)$ & $(0.639)$ & $(0.867)$ \\
\hline R\&Dstock ${ }^{\mathrm{F}}$ INVENTORS $\mathrm{x}$ ComRDout & & 0.839 & 0.504 & 0.751 \\
\hline & & $(0.523)$ & $(0.921)$ & $(0.776)$ \\
\hline Constant & $\begin{array}{l}1.322 * * \\
(0.043)\end{array}$ & $\begin{array}{l}1.459 * * \\
(0.035)\end{array}$ & $\begin{array}{l}1.671 * * \\
(0.031)\end{array}$ & $\begin{array}{l}1.705^{*} \\
(0.069)\end{array}$ \\
\hline Observations & 279 & 279 & 279 & 279 \\
\hline
\end{tabular}

Note: All variables are expressed in logs. All estimations include country and year fixed effects. $R \& D s t o c k^{D}$ is

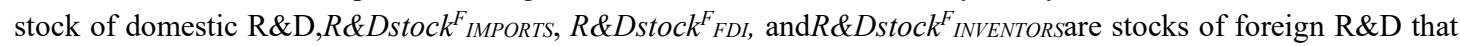
reach a country via the channel of imports (capital goods), FDI and inventor mobility, respectively.

abaseline estimation in column (1) includes only the effect of domestic and foreign knowledge, proxied by R\&D stocks.

${ }^{\mathbf{b}}$ Institutions estimations in columns (2) to (4) further include the effect of institutions namely, rule of law $(R L)$ in column (2), regulatory quality (RQ) in column (3) and the common factor for all six WGI indicators in column (4). Stars denote significance at the $1 \%{ }^{* * *}, 5 \% * *$ and $10 \% *$ level

$P$ values in Parentheses

In Table 3.4, we use the estimated weights for the construction of the economic proximity matrix and the results show an interesting deviation from the traditional approach. External contemporaneous innovation production in other countries appears to largely influence local patent production; an effect larger than that of own R\&D stock. Among the different channels of technology diffusion, it is that of trade that matter the most and then it is the mobility move and finally the FDI inflows. In other words, the more similar in trade intensity that countries are, the greater the benefits for the local innovation production. Furthermore, the more similar the countries are in inventors' mobility and FDI flows, the higher the local innovation production. All specifications in columns (2), (3) and (4) do provide statistically significant coefficients for foreign $R \& D$ independently from the definition of the corresponding transmission channel or institutional variable. Both the latter concluding remarks expand the discussion of the corresponding literature and provide significant insight about patent production. The literature does include a number of studies that support or enhance our results (Duverger and de la Potterie, 2011; Coe et al., 2008; Seck, 2012; $\mathrm{Xu}$ and Chiang, 2005). Interestingly, the choice of estimated rather than predetermined weights yields substantially higher coefficients for the external knowledge variables as one can see by comparing Tables 3 and 4. Having said that, we also note that the effect of the inventor channel is larger than the one of the FDI 
channel in these specifications and coefficients have increases almost eightfold compared to the first set of estimations. By contrast, the interaction terms appear not to be significant thus giving less vigor to the argument that good governance can cat as absorptive capacity. We argue that to avoid biased estimates, it is vital to consider carefully how to model spatial-temporal dynamics, common trends and common shocks, as well as how to account for the probable endogeneity of the technologically scaled external knowledge. Failure to model such is likely to bias the estimated coefficient, with the bias often being downward. Therefore, our model identifies appropriately patterns in the dependent variable that could lead to upward estimated coefficients in the specifications with estimated weights.

Overall, our estimates of domestic R\&D elasticity (0.23-0.38) are in the vicinity of estimates reported in the international spillover literature, and in particular in the studies of Drivas et al. (2016) (0.40-0.44), Peri (2005) (0.60-0.80), Pakes and Griliches (1980) (0.61), and in several other studies. Similarly, our estimates of external accessible $R \& D$ gained mainly through trade and inventor mobility are close to what the literature reports . Summing up, we find that knowledge flows are relevant to local innovation production as external accessible R\&D, gained through different channels, has a strong positive effect on a state's innovation activity. Second, the effective reach of knowledge, exemplified by capital goods imports, is larger than that of knowledge in inventors and FDI. Lastly, the quality of institutional setting in the host country greatly enhances the knowledge creation and abortion. The systematically greater effect of external knowledge after controlling for the endogeneity of the three transmission channels provides vigor to the argument that the spatial concentration of innovative activity (Saxenian, 1994 ; Verspagen, 1999; Keller, 2004; Crescenzi \& Rodriguez-Pose, 2011) is gradually receding and allowing for a more even geographical distribution of innovations (Saxenian, 2007). Our results are in line with the favorable implications for knowledge diffusion stemming from the declining communication costs and the ICT revolution underscored by Baldwin (2016). Especially through the channel of inventor mobility, a large part of the tacit element of knowledge creation is eradicated thus spurring greater spillover effects ${ }^{10}$.

\footnotetext{
${ }^{10}$ Storper \& Venables (2004) argue that the main factor behind the localized nature of technology spillovers is face-to-face interaction. With the free movement of talented individuals and the advanced technology on tele-presence this obstacle is minimized thus leading to increased knowledge transmission.
} 
Concerns, however, expressed in the literature for potential caveats in each channel approximating knowledge flows still pertain in the present study. For example, the mobility of inventors measure we employed here is based on patent data and so it does not catch the move of inventors that do not patent. However, by solely focusing on the very productive, in terms of patenting scientists, our measure captures the moves of the "high quality" scientists and, therefore, represents a lower bound of the 'true' inventor mobility effect. Overall, we are not expecting this measure to be biased across regions; however, we expected to find a very strong effect of distance confirmed by our estimates - as the way inventor's movement defined here requires significant patenting to be observed ${ }^{11}$. About the trade channel, disaggregation of imports into different categories (e.g., technological capital goods) would be a more insightful proxy of knowledge flows that operate via trade. Instead of relying on value of country's total imports we used the value of imports of capital goods which do embody advanced technology. Finally, the biggest challenges relates to the channel of FDI. According to the latest OECD vintage (OECD, 2015) of level and bilateral FDI data under the BMD4 definition, FDI flows are "cleaned" by reporting flows without accounting Special Purpose Entities (SPEs). The latter are firms that do not exert economic influence to the recipient economy and which account, for example, for a large part of total flows in countries like Luxembourg and the Netherlands (Bank of Greece, 2018). The relevant data on bilateral FDI flows does not offer this distinction prior to 2008; hence we use data on FDI flows according to the previous (BMD3) definition. Moreover, flows which pass through affiliates of the same parent company according to the Ultimate Controlling Parent ${ }^{12}$ definition, are not included in the updated FDI flows more than once after the initial flow as it would cause doublecounting. This correction is unfortunately also not available for the sample period in our sample.

\footnotetext{
${ }^{11}$ Instead of using inventors' job moves, one could use a more refine measure such as informal meetings and exchange of ideas of inventors during the inventive process (or probability to enter into local/international networks of research based on inventors' characteristics during the inventive process) as the study of Giuri and Mariani (2013) does. The latter, relies on survey data by interviewing European patent inventors about interactions that were important for the development of a patent. Such data, although very useful, is not yet available.
}

\footnotetext{
${ }^{12}$ Ultimate controlling parent (UCP): the entity proceeding up the affiliate's ownership chain that is not
} controlled by another entity (that is, owned more than $50 \%$ ). 


\subsubsection{Robustness}

We have performed several checks to sharpen the robustness of our results. We accounted for peculiar cases and outliers. Our main findings did not effetely alter. Further, we also consider other indices of institutions, namely the global competitiveness index, the financial efficiency index and the infrastructure quality index from the World Economic Forum (WEF) and the FDI restrictiveness index from the OECD. Overall, our major results pertain across different definitions of institutions. In addition, we include the lagged value of the foreign R\&D stock as the explanatory variable in our baseline specification in order to address the issue of endogeneity in a more conventional manner before applying the estimated weights. 


\subsection{Conclusion}

As noted in our introduction, analyzing the relationship between bilateral patents and bilateral trade requires an ambitious empirical framework. We observe a many-states where crossborder patents and trade flows each vary by origin, destination, industry, and time - to be denoted in the analysis by i, j, k, and t, respectively. We identified the effects of patents on trade by exploiting within origin-destination-industry (or "pairindustry") variation in both patents and trade. Part of what makes this task complex is the inter-connected nature of global and state trade. As has been well-known at least since Anderson and van Wincoop (2003), correctly assessing the determinants of bilateral trade between any two countries requires first recognizing the potentially confounding role played by multilateral factors such as market size and geography with respect to third states. 


\section{Chapter 4}

\section{Concluding Remarks}

Cross-state patenting is regarded anecdotally and theoretically as an important marker of growth and the spread of knowledge across states. But what the decision to file a patent in a particular trade partner can tell us about the motivations behind crossborder patents and their implications for trade remains an open question. To provide answers, we assemble a highly disaggregated data set of industry-level trade flows and cross-border patents, which we subject to a rich set of fixed effects that allow us to specifically isolate the bilateral dimension of the data for a given industry. Notably, ours is the first study to systematically investigate what the implications of bilateral patenting are for inter-state trade using a disaggregated data set. Our main finding is that bilateral patents in a given industry on average promote bilateral trade in that same industry, with no significant effect seen for imports returning in the opposite direction. However, we find these overall results mask substantial sources of heterogeneity across industries and across markets. Namely, we find very strong evidence that the pro-exporting effects exports from the patent-granting states to all destinations (i.e., not just to the country where the patent originated from). In our preferred specification, this type of spillover is absorbed by the fixed effects.

In general, it is hard to determine whether patents flow to sectors with fast productivity growth or whether foreign patents flowing to a particular sector independently contributes to changes in sectoral comparative advantage. This alone could be the subject of a future study building on the methods put forward in this thesis. Patents are concentrated in less-differentiated industries and slightly weaker (though still on the whole robust) evidence that import growth in less-differentiated industries is concurrently negatively affected. We also find some evidence the patents promote trade more strongly to more distant state markets. Taken together, these results support the interpretation that patents are used to preserve advantages in production costs and/or product quality versus foreign state competitors. Given that technology diffusion is a significant determinant of economic growth (c.f., Comin and Hobijn, 2010), we hope these findings can inform policies intended to stimulate innovation and promote the diffusion of knowledge. A further intended contribution 
of this thesis is our attempt to provide a methodology that can be used to analyze bilateral patent flows in conjunction with bilateral trade flows in a panel setting. By allowing patents to have effects that grow and decay over time and by pursuing a rigorous fixed effects specification that allows us to specifically isolate the withinindustry and within-pair dimension of the data, we are able to obtain estimates that we would argue are surprisingly well-identified in the face of natural concerns about reverse causality. For future work, an attractive extension would be to adopt a more structural approach in order to disentangle whether foreign state patents contribute to the transmission of technological comparative advantage in a manner consistent with theories of trade and growth. 


\section{References}

Acemoglu, D., and Robinson, J. (2012). Why Nations fail. The origins of power, prosperity and poverty. Currency.

Aitken, B.J., and Harrison, A.E. (1999). Do domestic firms benefit from direct foreign investment? Evidence from Venezuela. American Economic Review, 89(3), 605-618.

Alcacer, J., and Gittelman, M. (2006). Patent citations as a measure of knowledge flows: The influence of examiner citations. Review of Economics and Statistics, 88(4), 774-779.

Aghion, P., and Howitt, P. (1992). A model of growth through creative destruction. Econometrica, 60(2), 323-351.

Agrawal, A., Cockburne, I., and McHale, J. (2006). Gone But Not Forgotten: Knowledge Flows, Labor Mobility, and Enduring Social Relationships. Journal of Economic Geography, 6(5), 571-591.

Anselin, L., Varga, A., and Zoltan, A. (1997). Local Geographic Spillovers between University Research and High Technology Innovations. Journal of Urban Economics, 42(3), 422-448.

Audretsch, D.B., and Keilbach, M. (2008). Resolving the knowledge paradox: Knowledge-spillover entrepreneurship and economic growth. Research Policy, 37(10), 1697-1705.

Audretsch, D., and Stephan, P. E. (1996). Company-scientist locational links: The case of biotechnology. American Economic Review, 86(3), 641-652.

Baldwin, R. (2016). The Real Convergence. Information Technology and the New Globalization, Harvard University Press. 
Bénassy-Quéré, A., Coupet, M., and Mayer, T. (2007). Institutional Determinants of Foreign Direct Investment. The World Economy, 30(5), 764-782.

Benos, N., Karagiannis, S., and Karkalakos, S. (2015). Proximity and growth spillovers in European regions: The role of geographical, economic and technological linkages. Journal of Macroeconomics, 43, 124-139.

Blalock G., and Gertler P. J. (2008). Welfare gains from foreign direct investment through technology transfer to local suppliers. Journal of International Economics, 74(2), $402-421$.

Bottazzi, L., and Peri, G. (2003). Innovation and spillovers in regions: Evidence from European patent data. European Economic Review, 47(4), 687-710.

Branstetter, L. (2001). Are Knowledge Spillovers International or Intranational in Scope? Microeconometric Evidence from the U.S. and Japan. Journal of International Economics, 53(1), 53-79.

Branstetter, L. (2006). Is foreign investment a channel of knowledge spillovers? Evidence from Japan's FDI in the United States. Journal of International economics, 68(2), 325344.

Bowen, W. M., Mikelbank, B. \& Prestegaard, D. M., 2001. Theoritical and empirical considerations regarding space in hedonic housing price model applications. Growth and Change, (32), pp. 466-490.

Bruno, R., Bytchkova, M., and Estrin, S. (2011). Institutions and entry: A cross-regional analysis in Russia. IZA Discussion Papers, No. 5504.

Canton, E. and Solera, I. (2016). Greenfield Foreign Direct Investment and Structural 
Reforms in Europe: What Factors Determine Investments?. EC Discussion Paper 033.

Coe, D. T., and Helpman, E. (1995). International R\&D Spillovers. European Economic Review, 39(5), 859-887.

Coe, D. T., and Hoffmaister, A. (1999). Are there international R\&D spillovers among randomly matched trade partners? A response to Keller. IMF working paper.

Coe, D. T, Helpman, E., and Hoffmaister A. (2009). International R\&D Spillovers and Institutions, European Economic Review, 53(7), 723-741.

Cohen, W. M., and Levinthal, D. (1989). Absorptive capacity: a new perspective on learning and innovation. Administrative Science Quarterly, 35(1), 128-152.

Crescenzi, R., and Rodriguez-Pose, A. (2011). Innovation and Regional Growth in the European Union. Springer Science \& Business Media.

Crescenzi, R., and Gagliardi, L. (2018). The innovative performance of firms in heterogeneous environments: The interplay between external knowledge and internal absorptive capacities. Research Policy, 47(4), 782-795.

Cull, R., and Xu, L. (2005). Institutions, ownership, and finance: The determinants of profit reinvestment among Chinese firms. Journal of Financial Economics, 77(1), 117146.

Dellis, K., (2018). Structural Determinants of FDI Inflows and the case of Greece, Bank of Greece Economic Bulletin, 54.

Dellis, K, Sondermann, D., and Vansteenkiste, I. (2017). Determinants of FDI inflows in advanced economies: Does the quality of economic structures matter? ECB Working Paper 2066. 
Deltas, G., and Karkalakos, S. (2013). Similarity of R\&D Activities, Physical Proximity and R\&D Spillovers. Regional Science and Urban Economics, 43(1), 124-131.

Drivas, K., Economidou, C., and Karkalakos, S. (2014). Spatial Aspects of Innovation Activity in the US, Journal of the Knowledge Economy, 5(3), 464-480.

Drivas, K., Economidou, C., Karkalakos, S., and Tsionas, E. G. (2016). Mobility of knowledge and local innovation activity. European Economic Review, 85, 39-61.

Drivas, K., Economidou, C., Karamanis, D., and Sanders, M. (2020). Mobility of highly skilled individuals and local innovation activity. Technological Forecasting and Social Change, 158, 120144.

Duverger, C., and De La Potterie, B. V. P. (2011). Determinants of productivity growth: Science and technology policies and the contribution of R\&D. European Investment Bank Papers, 16(1), 52-61.

European Commission (2018), European Innovation Scoreboard.

Feldman, M. P. (1999). The new economics of innovation, spillovers and agglomeration: A review of empirical studies. Economics of innovation and new technology, 8(1-2), 525.

Feldman, M.P. (2000). Location and innovation: the new economic geography of innovation, spillovers and agglomeration. In: Clark, G.L., Feldman, M.P., Gertler, M.S. (Eds.), The Oxford Handbook of Economic Geography, Oxford University Press, Oxford, 373-394.

Feldman, M. P., and Kogler, D. (2010), Stylized Facts in the Geography of Innovation. In , Handbook of the Economics of Innovation, 1, 381-410. 
Gagliardi, L. (2015). Does skilled migration foster innovative performance? Evidence from British local areas. Papers in Regional Science, 94(4), 773-794.

Georgiadis, G. (2017). To bi, or not to bi? Differences between Spillover Estimates from Bilateral and Multilateral Multi-country Models. Journal of International Economics, 107, 1-18.

Gorodnichenko, Y., Svejnar, J., and Terrell, K. (2014). When does FDI havepositive spillovers? Evidence from 17 transition market economies. Journal of Comparative Economics, 42 (4), 954-969.

Griliches Z. (1992) The search for R\&D spillovers. Scandinavian Journal of Economics, 94, 29-47.

Griliches, Z. (1979). Issues in assessing the contribution of research and development to productivity growth. The Bell Journal of Economics, 10(1), 92-116.

Grossman, G., and Helpman, E. (1991). Innovation and Growth in the Global Economy. MIT Press.

Giuri, P., and Mariani, M. (2013). When distance disappears: Inventors, education, and the locus of knowledge spillovers. Review of Economics and Statistics, 95(2), 449-463.

Hall, R., and Jones, C.I. (1999). Why do some countries produce so much more output per worker than others? Quarterly Journal of Economics, 114(1), 83-116.

Haskel, J. E.; Pereira, S. C., and Slaughter, M. J. (2007). Does inward foreign direct investment boost the productivity of domestic firms? The Review of Economics and Statistics, 89(3), 482-496. 
Hausmann, R., Hwang, J., and Rodrik, D. (2007). What you export matters. Journal of Economic Growth, 12(1), 1-25.

Jaffe, A., and Trajtenberg, M. (2002). Patents, Citations and Innovations: A Window on the Knowledge Economy. Cambridge: MIT Press.

Jaffe, A., Trajtenberg, M., and Henderson, R. (1993). Geographic localization of knowledge spillovers as evidenced by patent citations. Quarterly Journal of Economics 108(3), 577-598.

Javorcik, B.S. (2004). Does foreign direct investment increase the productivity of domestic firms? In search of spillovers through backward linkages. American Economic Review, 94(3), 605-627.

Javorcik, B., and Wei, S. (2009). Corruption and cross-border investment in emerging markets: Firm-level evidence. Journal of International Money and Finance, 28(4), 605624.

Javorcik, B.S., and Spatareanu, M. (2008). To share or not to share: Does local participation matter for spillovers from foreign direct investment?. Journal of development Economics, 85(1-2), 194-217.

Keller, W. (2004). International Technology Diffusion. Journal of Economic Literature, 42(3), 752-782.

Kelejian, H. H. \& Prucha, I. R., 2007. Prediction efficiencies in spatial models with spatial lags. Regional Science and Urban Economics, 37(3), 363-374.

Kim, C. W., Phipps, T. T. \& Anselin, L., 2003. Measuring the benefits of air quality improvement: A spatial hedonic approach. Journal of Environmental Economics and Management, 45, 24-39. 
Kim, J., and Marschke, G., (2005). Labor mobility of scientists, technological diffusion, and the firm's patenting decision. RAND Journal of Economics, 36(2), 298-317.

Lee, G. (2005). Direct versus Indirect International R\&D Spillovers. Information Economics and Policy, 17(3), 334-348.

Lenzi, C. (2009). Patterns and determinants of skilled workers' mobility: evidence from a survey of Italian inventors. Economics of Innovation and New Technology, 18(2), 161179.

Levchenko, A. A. (2007). Institutional quality and international trade. Review of Economic Studies, 74(3), 791-819.

Lichtenberg, F.R., and De La Potterie, B.V.P. (1998). International R\&D spillovers: A reexamination. European Economic Review, 42(8), 1483-1491.

Mancusi, M. L. (2008). International spillovers and absorptive capacity: A cross-country cross-sector analysis based on patents and citations. Journal of International Economics, 76(2), 155-165.

Mauro, P. (1995). Corruption and growth. Quarterly Journal of Economics, 110(3), 681712.

McNeil, L., and Fraumeni, B. (2005). International trade and economic growth: A possible methodology for estimating cross-border R\&D spillovers., BEA Working Paper 2005-03.

Miguelez, E., and Fink, C. (2013). Measuring the international mobility of inventors: A new database, WIPO Economics \& Statistics Series, Working Paper No.8. 
Miguelez, E., Moreno, R., and Surinach, J. (2010). Inventors on the move: Tracing inventors' mobility and its spatial distribution. Papers in Regional Science, 89(2), 251274.

Miguélez, E., and Moreno, R. (2014). What attracts knowledge workers? The role of space and social networks. Journal of Regional Science, 54(1), 33-60.

Nunn, N., (2007). Relationship-specificity, incomplete contracts, and the patten of trade. Quarterly Journal of Economics, 122(2), 569-600.

OECD (2015). Implementing the latest international standards for compiling foreign direct investment statistics, www.oecd.org/investment/statistics.htm.

OECD (2016). Anti-bribery Ministerial Meeting, OECD Conference Center Paris.

Pakes, A., and Griliches, Z. (1980). Patents and R\&D at the firm level: A first report. Economics Letters, 5(4), 377-381.

Peri, G. (2005). Determinants of Knowledge Flows and their Effect on Innovation. The Review of Economics and Statistics, 87(2), 308-322.

Petit, M. L., Sanna-Randaccio, F., and Sestini, R. (2012). R\&D and foreign direct investment with asymmetric spillovers. Economics of Innovation and New Technology, 21(2), 125-150.

Rivera-Batiz, L., and Romer, P. (1991). Endogenous Growth and Economic Integration. Quarterly Journal of Economics, 106(2), 531-555.

Robinson, J., Acemoglu, D., and Johnson, S., (2005). Institutions as a fundamental cause of long-run growth. Handbook of Economic Growth, 1, 385-472. 
Rodríguez-Pose, A., and Di Cataldo, M. D. (2014). Quality of government and innovative performance in the regions of Europe. Journal of Economic Geography, 15(4), 673-706.

Romer, P.M. (1986). Increasing returns and long-run growth. Journal of Political Economy, 94(5), 1002-1037.

Saxenian, A. (1994). Regional Advantage: Culture and Competition in Silicon Valley and Route 128. Harvard University Press.

Saxenian, A (2007). The New Argonauts. Regional Advantage in a Global Economy. Harvard University Press.

Seck, A. (2012). International technology diffusion and economic growth: Explaining the spillover benefits to developing countries. Structural Change and Economic Dynamics, 23(4), 437-451.

Storper, M., and Venables, A. (2004). Buzz: Face-To-Face Contact and the Urban Economy. Journal of Economic Geography, 4(4), 351-370.

Swan, J., Newell, S., Scarbrough, H., and Hislop, D. (1999). Knowledge management and innovation: networks and networking. Journal of Knowledge Management, 3(4), 262-275.

UNCTAD, F. (2020). Foreign direct investment: Inward and outward flows and stock, annual, Available at:

https://unctadstat.unctad.org/wds/TableViewer/tableView.aspx?ReportId=96740

Verspagen, B. (1999). European regional clubs: Do they exist and where are they heading? on economic and technological differences between European regions. In: Adams, J., Pigliaru, F. (Eds.), Economic Growth and Change: National and Regional Patterns of Convergence and Divergence. Edward Elgar, Cheltenham, 236-256. 
Veugelers, R. (2017). Missing Convergence in Innovation Capacity: Facts and Policy Implications. European Economy Discussion Paper 066.

$\mathrm{Xu}$, B., and Chiang, E. P. (2005). Trade, patents and international technology diffusion. The Journal of International Trade \& Economic Development, 14(1), 115-135. 


\section{Appendix}

Table A.1: The Distribution of Patents, R\&D of Firms and Universities, and Employment in USA [2000-2017]

\begin{tabular}{|c|c|c|c|}
\hline Variables & Ranges (Counts) & States & $\begin{array}{l}\text { Cumulative } \\
\text { Percentages }\end{array}$ \\
\hline \multirow{5}{*}{ Patents } & $0.1-5$ & 34 & $21.66 \%$ \\
\hline & $5.1-10$ & 28 & $39.49 \%$ \\
\hline & $10.1-30$ & 54 & $73.89 \%$ \\
\hline & $30.1-100$ & 37 & $97.45 \%$ \\
\hline & $100.1-338$ & 4 & $100.00 \%$ \\
\hline \multirow{5}{*}{ R\&D of Firms } & $0.1-9$ & 28 & $17.83 \%$ \\
\hline & $9.1-18$ & 46 & $47.13 \%$ \\
\hline & $18.1-40$ & 42 & $73.89 \%$ \\
\hline & $40.1-80$ & 33 & $94.90 \%$ \\
\hline & $80.1-890$ & 8 & $100.00 \%$ \\
\hline \multirow{5}{*}{ R\&D of Universities } & $0.1-6$ & 24 & $15.29 \%$ \\
\hline & $6.1-12$ & 47 & $45.22 \%$ \\
\hline & $12.1-20$ & 39 & $70.06 \%$ \\
\hline & $20.1-70$ & 38 & $94.27 \%$ \\
\hline & $70.1-180$ & 9 & $100.00 \%$ \\
\hline \multirow{5}{*}{$\begin{array}{l}\text { Employment at } \\
\text { Universities }\end{array}$} & $0.1-150$ & 31 & $19.75 \%$ \\
\hline & $151.1-320$ & 43 & $47.13 \%$ \\
\hline & $320.1-470$ & 33 & $68.15 \%$ \\
\hline & $470.1-710$ & 34 & $89.81 \%$ \\
\hline & $710.1-934$ & 16 & $100.00 \%$ \\
\hline \multirow{5}{*}{$\begin{array}{l}\text { Employment at } \\
\text { Firms }\end{array}$} & $0.1-200$ & 30 & $19.11 \%$ \\
\hline & $200.1-400$ & 30 & $38.22 \%$ \\
\hline & $400.1-600$ & 57 & $74.52 \%$ \\
\hline & $600.1-800$ & 31 & $94.27 \%$ \\
\hline & $800.1-911$ & 9 & $100.00 \%$ \\
\hline \multirow{5}{*}{ Scientists and Engineers } & $0.1-50$ & 38 & $24.20 \%$ \\
\hline & $50.1-70$ & 32 & $44.59 \%$ \\
\hline & $70.1-90$ & 21 & $57.96 \%$ \\
\hline & $90.1-120$ & 37 & $81.53 \%$ \\
\hline & $120.1-179$ & 29 & $100.00 \%$ \\
\hline \multirow{5}{*}{ Volume of Trade Flows } & $0.1-100$ & 18 & $24.20 \%$ \\
\hline & $100.1-400$ & 42 & $44.59 \%$ \\
\hline & $400.1-900$ & 47 & $57.96 \%$ \\
\hline & $900.1-1200$ & 31 & $81.53 \%$ \\
\hline & $1200.1-1679$ & 19 & $100.00 \%$ \\
\hline \multirow{5}{*}{$\begin{array}{c}\text { Employment at } \\
\text { High Technology-Firms }\end{array}$} & $0.1-5$ & 43 & $27.39 \%$ \\
\hline & $5.1-10$ & 42 & $54.14 \%$ \\
\hline & $10.1-18$ & 40 & $79.62 \%$ \\
\hline & $18.1-30$ & 14 & $88.54 \%$ \\
\hline & $30.1-138$ & 18 & $100.00 \%$ \\
\hline
\end{tabular}

Source: Burau of Labor Statistic, USA [20017] 
Table A.2: Descriptive ${ }^{1}$ Statistics of Data

\begin{tabular}{|c|c|c|c|c|c|c|c|c|c|}
\hline $\begin{array}{c}\text { Statistics } \\
-\begin{array}{c}\text { Variables } \\
\text { HT - Patents }\end{array}\end{array}$ & 11.92 & 8.96 & 14.07 & 68.22 & 4653.33 & 55.72 & 7.41 & 2.02 & 517.63 \\
\hline $\begin{array}{c}\text { R\&D of } \\
\text { Firms }\end{array}$ & 36.30 & 3.85 & 26.34 & 29.33 & 860.38 & -1.12 & 0.53 & 5.00 & 96.70 \\
\hline $\begin{array}{c}\text { R\&D of } \\
\text { Universities }\end{array}$ & 13.82 & 1.31 & 11.78 & 9.96 & 99.27 & 2.79 & 1.31 & 2.00 & 51.83 \\
\hline $\begin{array}{c}\text { Employment }{ }^{4} \text { at } \\
\text { Firms }\end{array}$ & 508.32 & 43.14 & 477.74 & 328.57 & 1079.50 & -1.51 & 0.08 & 17.00 & 1000.00 \\
\hline $\begin{array}{c}\text { Employment at } \\
\text { Universities }\end{array}$ & 491.68 & 43.14 & 522.26 & 388.12 & 959.44 & -2.51 & -0.89 & 10.00 & 1000.00 \\
\hline
\end{tabular}

${ }^{1}$ All the variables were standardized using the Total Employment of each region.

${ }^{2}$ HT - Patents denote total number of patent applications per state.

${ }^{3}$ R\&D of Firms, and Universities denotes expenditures per state in million of dollars at 1995 prices.

${ }^{4}$ Employment at Firms and Universities refers to the total number of employees (Head Count) per state. 